\begin{tabular}{|c|}
\hline $\begin{array}{c}\text { 2. To: (Receiving Organization) } \\
\text { Distribution }\end{array}$ \\
\hline 5. Proj./Prog./Dept./Div.: \\
\hline $\begin{array}{l}\text { Data Report for Catch Tank } \\
\text { Vapor Samp } 11 \text { ing/River } \\
\text { Protection Project/DD\&I/DST } \\
\text { Engineering }\end{array}$ \\
\hline
\end{tabular}

8. Originator Remarks:

This document is being released into the supporting document system for retrievability purposes.
4. Related EDT No.:

$N / A$

7. Purchase Order No.:
7. Purchase Order No.
N/A
11. Receiver Remarks: 11A. Design Baseline Document? [] Yes [X] No For release.
9. Equip./Component No.: $\mathrm{N} / \mathrm{A}$

10. System/Bldg./Facility: $N / A$

12. Major Assm. Dwg. No.: $\mathrm{N} / \mathrm{A}$

13. Permit/Permit Application No.: $\mathrm{N} / \mathrm{A}$

14. Required Response Date: 09/19/00

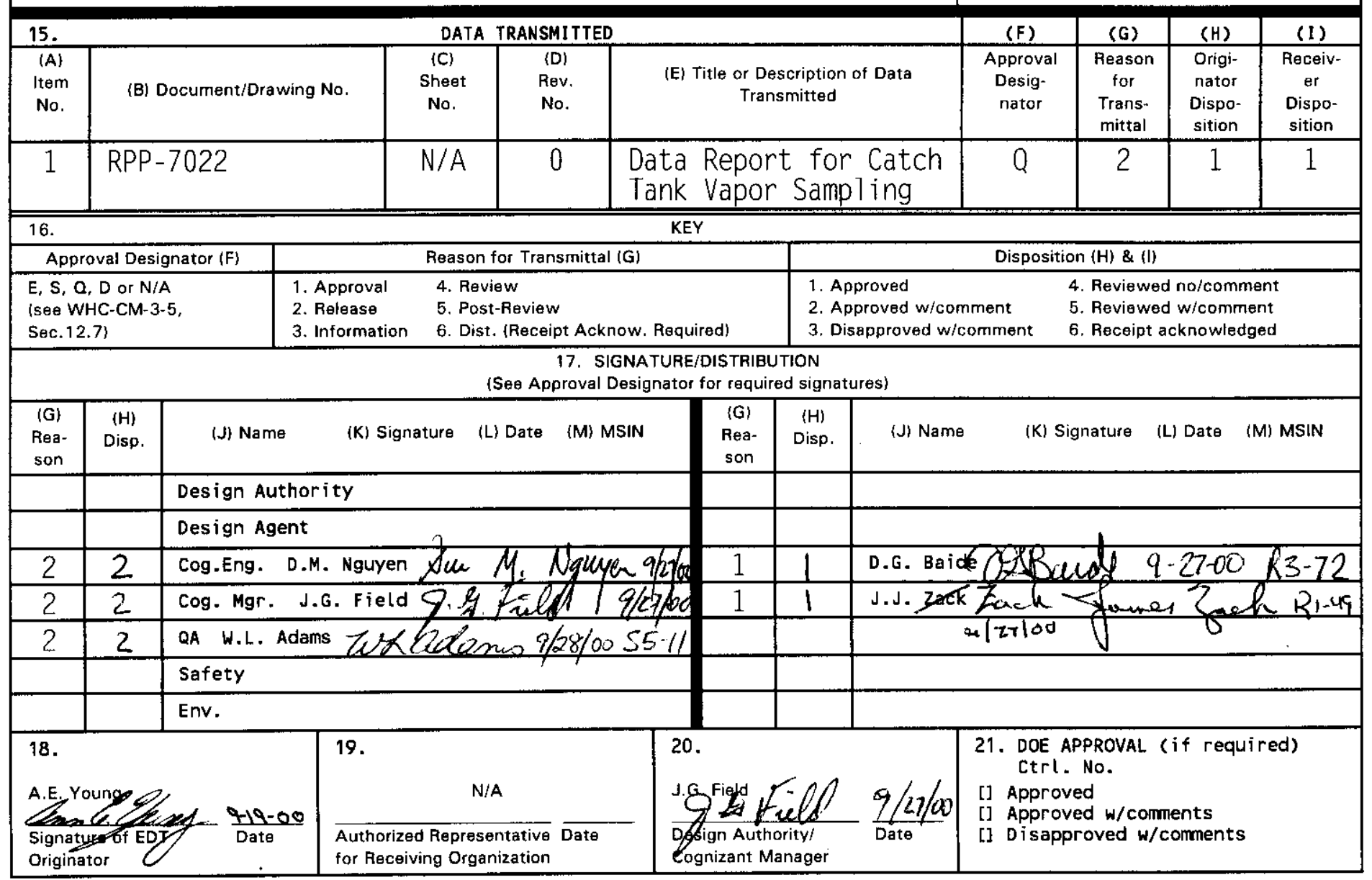

BD-7400-172-2 (05/96) GEF097 


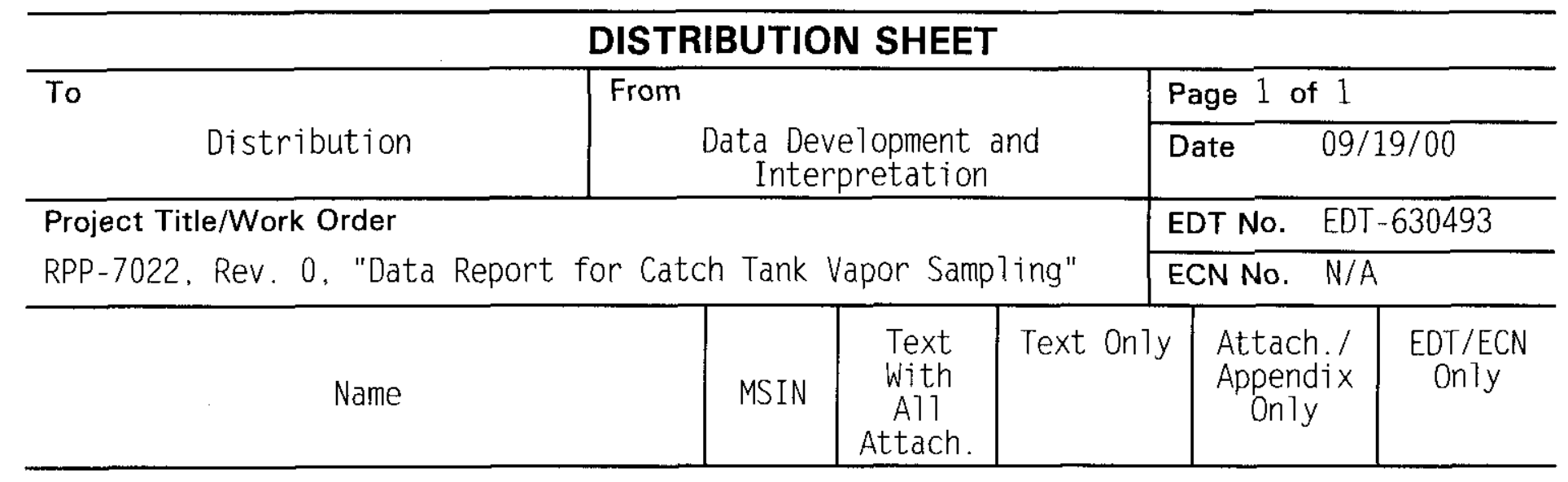

CH2M Hill Hanford Group, Inc.

W. L. Adams

W. B. Barton

D. A. Bragg

D. G. Baide

R. J. Cash

J. G. Field

K. M. Hodgson

G. D. Johnson

P. F. Kison

D. M. Nguyen

L. M. Sasaki

D. D. Wanner

T.C.S.R.C.

Fluor Hanford

K. L. Powell

R. S. Viswanath

H \& R Technical Associates

L. J. Kripps

Lockheed Martin Services. Inc.

Central Files

Longenecker and Associates

J.3. Zach

Office of River Protection

DOE Reading Room

Pacific Northwest National Laboratory

S. J. Bos

J. W. Brothers
S6-15

R2-11

S5-05

R3-72

R1 -44

R2-12

R2-11

R1-44

T4- 07

R2-12

R2-12

S7 -12

R1-10

S3-30

S3-30

$x$
$x$
$x$
$x$
$x$
$x$
$x$
$x$
$x$
$x$
$x$
$x$
$x$

R1-44 X

B1-07 X

R1-49 X

H2-53 X

P7 -22

K9-20
$X$
$x$

$x$
$x$ 


\title{
Data Report for Catch Tank Vapor Sampling
}

\author{
Duc M. Nguyen \\ CH2M HILL Hanford Group, Inc., Richland, WA 99352 \\ office of River Protection Contract DE-AC06-99RL14047 \\ $\mathrm{EDT} / \mathrm{ECN}: \quad \mathrm{EDT}-630493$ \\ Org Code: $7 \mathrm{NKOO}$ \\ UC: $\quad 2070$ \\ B\&R Code: EW 3120074 \\ $\mathrm{CACN} / \mathrm{COA}: \quad 101922 / \mathrm{ES} 30$ \\ Total Pages: 40 \\ Key Words: Catch Tank, Vapor Sampling, Flammable Gas, Hydrogen \\ Abstract: $\quad \mathrm{N} / \mathrm{A}$
}

\section{Tradenames:}

SUMMA is a trademark of Moletrics, Inc., cleveland, ohio

Hoke is a trademark of Hoke Incorporated, Cresskill, New Jersey

Draeger is a trademark of Draegerwerk, Germany

ENRAF is a trademark of the ENRAF Corporation, Houston, Texas

TRADEMARK DISCLAIMER. Reference herein to any specific commercial product, process, or service by trade name, trademark, manufacturer, or otherwise, does not necessarily constitute or imply its endorsement, recommendation, or favoring by the United States Government or any agency thereof or its contractors or subcontractors.

Printed in the United States of America. To obtain copies of this documentucontact: Document Control Services, P.O. Box 950, Mailstop H6-08, Richland WA 99352, Phone (509) 372-2420; Fax (509) 376-4989.
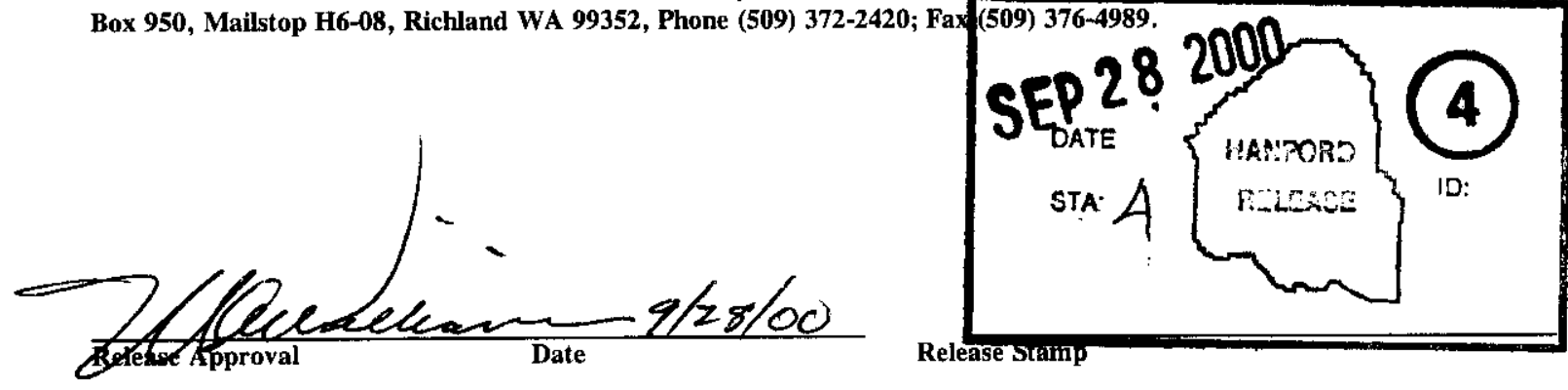

\section{Approved for Public Release}


RPP-7022

Revision 0

\section{DATA REPORT FOR CATCH TANK VAPOR SAMPLING}

D. M. Nguyen

CH2M HILL Hanford Group, Inc.

Date Published

September 2000

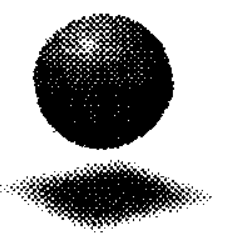

\section{CH2MHILL \\ Hantord Group, inc,}

Prepared for the U. S. Department of Energy

Office of River Protection 
RPP-7022 Rev. 0

\section{TABLE OF CONTENTS}

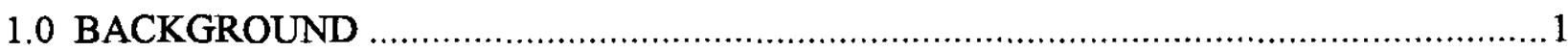

2.0 SCOPE

3.0 DISCUSSION OF FLAMMABLE GAS LEVEL MEASUREMENTS ..............................2

3.1 FLAMMABLE GAS MEASUREMENTS FOR TANK 241-S-304 .......................... 2

3.2 FLAMMABLE GAS MEASUREMENTS FOR TANK 241-ER-311 ........................

3.2.1 Vapor Sampling from Tank 241-ER-311 East Riser........................................4

3.2.2 Vapor Sampling from Tank 241-ER-311 West Riser ...................................... 6

3.2.3 Vapor Sampling from Piping and Equipment Connected to Tank 241-ER-311 ...7

3.3 FLAMMABLE GAS MEASUREMENTS FOR TANK 241-A-417.........................

3.4 FLAMMABLE GAS MEASUREMENTS FOR TANK 241-EW-151 .......................10

3.5 FLAMMABLE GAS MEASUREMENTS FOR TANK 241-A-302A $\ldots \ldots \ldots \ldots \ldots \ldots \ldots \ldots . . . \ldots \ldots$

3.6 FLAMMABLE GAS MEASUREMENTS FOR TANK 241-UX-302A …..................12

3.7 FLAMMABLE GAS MEASUREMENTS FOR TANK 241-U-301B …....................13

3.8 FLAMMABLE GAS MEASUREMENTS FOR TANK 241-TX-302C .....................14

3.9 FLAMMABLE GAS MEASUREMENTS FOR TANK 241-AZ-151 …….............. 15

3.10 FLAMMABLE GAS MEASUREMENTS FOR TANK 241-AZ-154 ….................16

3.11 FLAMMABLE GAS MEASUREMENTS FOR TANK 241-A-350 ......................17

3.12 FLAMMABLE GAS MEASUREMENTS FOR TANK 204-AR-TK-1 …................18

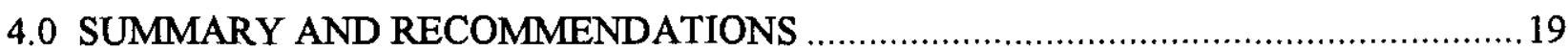

5.0 REFERENCES

\section{APPENDICES}

APPENDIX A. SUMMARY OF VAPOR SAMPLING DATA FOR CATCH

TANK 241-ER-311 
RPP-7022 Rev. 0

\section{LIST OF FIGURES}

Figure 3-1. Configuration of Catch Tank 241-ER-311 and Associated Equipment 8

\section{LIST OF TABLES}

Table 3-1. Flammable Gas Measurements for Catch Tank 241-S-304 ................................3

Table 3-2. Tank 241-ER-311 East Riser Vapor Sampling Activities................................... 5

Table 3-3. Tank 241-ER-311 West Riser Vapor Sampling Activities...............................6

Table 3-4. Vapor Sampling Activities for Piping and Equipment Connected to

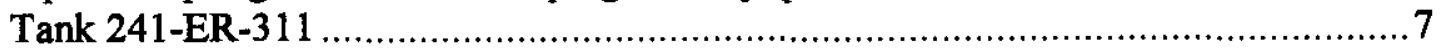

Table 3-5. Flammable Gas Measurements for Catch Tank 241-A-417 ..............................9

Table 3-6. Flammable Gas Measurements for Catch Tank 241-EW-151 ............................ 10

Table 3-7. Flammable Gas Measurements for Catch Tank 241-A-302A A..............................11

Table 3-8. Flammable Gas Measurements for Catch Tank 241-UX-302A ........................... 12

Table 3-9. Flammable Gas Measurements for Catch Tank 241-U-301B ............................ 13

Table 3-10. Flammable Gas Measurements for Catch Tank 241-TX-302C ........................... 14

Table 3-11. Flammable Gas Measurements for Catch Tank 241-AZ-151.......................... 15

Table 3-12. Flammable Gas Measurements for Catch Tank 241-AZ-154.......................... 16

Table 3-13. Flammable Gas Measurements for Catch Tank 241-A-350 .............................. 17

Table 3-14. Flammable Gas Measurements for Catch Tank 204-AR-TK-1 ........................ 18

Table A-1. Combustible Gas Meter (CGM) Results from East Riser. .................................3

Table A-2. Hoke ${ }^{T M}$ Sample Results from East Riser .............................................

Table A-3. SUMMA ${ }^{\text {TM }}$ Sample Results from East Riser ........................................... A 
RPP-7022 Rev. 0

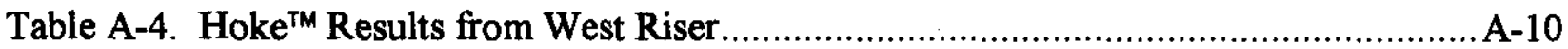

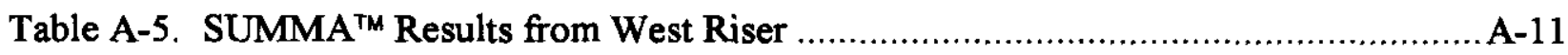

Table A-6. Hoke ${ }^{T M}$ Results from Interconnected Piping and Equipment …….................... A-13

\section{LIST OF TERMS}

CGM combustible gas meter

CHG CH2M HILL Hanford Group, Inc.

DQO data quality objective

FY fiscal year

gal gallon(s)

HEPA high-efficiency particulate air

LFL lower flammability limit

LMHC Lockheed Martin Hanford Corporation

$\mathrm{mL} \quad$ milliliter

OVM organic vapor meter

PNNL Pacific Northwest National Laboratory

ppm parts per million

RPP River Protection Project

WSCF Waste Sampling and Characterization Facility 
RPP-7022 Rev. 0

\section{DATA REPORT FOR CATCH TANK VAPOR SAMPLING}

\subsection{BACKGROUND}

CH2M HILL Hanford Group, Inc. (CHG) is responsible for developing and maintaining the authorization basis for River Protection Project (RPP) facilities and operations. This responsibility includes closure of the Flammable Gas Unreviewed Safety Question (USQ) for waste tank ancillary equipment such as catch tanks, double-contained receiver tanks, 244-AR and 244-CR vaults, 242-S and 242-T Evaporators, and inactive miscellaneous underground storage tanks. To support closure of the Flammable Gas USQ for catch tanks, an analysis of the flammable gas hazard was performed. Data is needed to verify flammable gas level assumptions in the hazard analysis. The Test Plan for Measuring Ventilation Rates and Combustible Gas Levels in RPP Catch Tanks (Nguyen 2000) was prepared in accordance with the Tank Safety Screening Data Quality Objectives (DQO) (Dukelow et al. 1995) to provide requirements and guidelines for the data collection.

The Tank Waste Remediation System Final Safety Analysis Report (FSAR) (CHG 2000a) identifies 13 RPP catch tanks: 241-A-302A, 241-TX-302C, 241-U-301B, 241-UX-302A, 241-ER-311, 241-AX-152, 241-EW-151, 241-S-304, 241-AZ-151, 241-AZ-154, 241-A-417, 204-AR-TK-1, and 241-A-350. In fiscal year (FY) 2000, flammable gas levels in the headspace of twelve catch tanks (other than 241-AX-152) were measured using a combustible gas meter (CGM). Ammonia and organic concentrations were also measured to differentiate the type of flammable gas (i.e., hydrogen, ammonia, or organic vapor). Hydrogen, ammonia, and organics are the most commonly observed flammable gas species in the Hanford tank farm system. Ammonia and organic vapor concentrations were measured using Draeger ${ }^{1}$ meter and organic vapor meter (OVM), respectively. Measurements of flammable gas level, ammonia, and organic concentrations in tank 241-AX-152 were not performed in FY 2000 because of schedule and resource constraints, but are planned for FY 2001.

In addition, tracer gas injection was performed for two tanks, 241-EW-151 and 241-A-350, to estimate the ventilation rates. Ventilation removes flammable gas from a tank headspace. Tank 241-EW-151 is passively ventilated while $241-\mathrm{A}-350$ has a small air flow through its dip tubes. Measuring the ventilation rates in these tanks provides an estimate of airflow rates through the catch tanks. A known amount of helium was injected into a tank headspace. Samples of headspace gas were then taken at measured time intervals. The samples will be analyzed for helium concentration. Ventilation rate for the tank will be calculated based on the decrease in the measured helium concentration between these points in time. Samples of helium-injected headspace gas from the two tanks were collected in FY 2000 but analytical data will not be available until FY 2001. This document will be updated to include the tracer gas injection data (and tank 241-AX-152 flammable gas level data) when it becomes available.

${ }^{1}$ Draeger is a trademark of Draegerwerk, Germany. 


\subsection{SCOPE}

This document provides a summary of flammable gas data obtained from RPP active catch tanks in FY 2000. Flammable gas level measurements for each catch tank (other than 241-AX-152) are discussed on a tank-by-tank basis in Section 3.0. Conclusions based on the data are provided in Section 4.0. This section also includes recommendations that would be useful when conducting vapor sampling for other miscellaneous tanks (e.g., inactive miscellaneous underground storage tanks).

As discussed earlier, this report will be updated to include flammable gas data for tank 241-AX-152 and tracer gas injection data for tanks 241-EW-151 and 241-A-350 when the data becomes available.

\subsection{DISCUSSION OF FLAMMABLE GAS LEVEL MEASUREMENTS}

Flammable gas level measurements are discussed according to the order in which the tanks were sampled. The order is as follows:

$$
\begin{aligned}
& \text { 241-S-304, } \\
& \text { 241-ER-311, } \\
& \text { 241-A-417, } \\
& \text { 241-EW-151, } \\
& \text { 241-A-302A, } \\
& \text { 241-UX-302A, } \\
& \text { 241-U-301B, } \\
& \text { 241-TX-302C, } \\
& \text { 241-AZ-151, } \\
& \text { 241-AZ-154, } \\
& \text { 241-A-350, and } \\
& \text { 204-AR-TK-1. }
\end{aligned}
$$

\subsection{FLAMMABLE GAS MEASUREMENTS FOR TANK 241-S-304}

Catch tank 241-S-304 is located east of the SX tank farm in the 200 West Area. The tank is made of carbon steel and has a maximum capacity of $6,300 \mathrm{gal}$. It receives drainage from the 241-S-151 diversion box (Palit 1996). The tank is passively ventilated through a breather filter (CHG 2000a).

Flammable gas measurements for catch tank 241-S-304 were performed on October 28, 1999. The tank was nearly empty at the time of sampling. Access to the tank headspace was through Riser 4. Combustible gas meter (CGM), OVM, and Draeger ${ }^{\mathrm{TM}}$ readings were taken from 3 and 26 feet below the top of the riser. The combustible gas reading near the top of the riser was required by the Technical Safety Requirements (TSR) for tank entry (CHG 2000b). Readings at the 26 foot depth were inside the tank headspace. Readings inside the headspace are preferred 
for the intended use because they are considered more representative of the flammable gas contents of the tank. Multiple readings at this depth were taken to verify repeatability of results.

Flammable gas measurements for tank 241-S-304 are summarized in Table 3-1. Combustible gas meter (CGM) results are reported in terms of percent of the lower flammability limit (LFL); OVM and Draeger ${ }^{\mathrm{TM}}$ meter results are reported as parts per million (ppm).

Table 3-1. Flammable Gas Measurements for Catch Tank 241-S-304

\begin{tabular}{|c|c|c|c|}
\hline Wodsition & 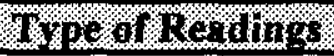 & Instrunent Used? & Serouls \\
\hline \multirow{3}{*}{$\begin{array}{c}3 \text { feet below top of } \\
\text { riser }\end{array}$} & Flammable Gas & CGM & $0 \%$ of LFL \\
\hline & Organic Vapor & OVM & $0 \mathrm{ppm}$ \\
\hline & Ammonia & Draeger $^{\mathrm{TM}}$ & $<5 \mathrm{ppm}$ \\
\hline \multirow{3}{*}{$\begin{array}{c}\text { Within tank } \\
\text { headspace } \\
\text { (first set) }\end{array}$} & Flammable Gas & CGM & $0 \%$ of LFL \\
\hline & Organic Vapor & OVM & $0 \mathrm{ppm}$ \\
\hline & Ammonia & Draeger $^{\mathrm{TM}}$ & $<5 \mathrm{ppm}$ \\
\hline \multirow{3}{*}{$\begin{array}{l}\text { Within tank } \\
\text { headspace } \\
\text { (second set) }\end{array}$} & Flammable Gas & CGM & $0 \%$ of LFL \\
\hline & Organic Vapor & OVM & $0 \mathrm{ppm}$ \\
\hline & Ammonia & Draeger $^{\top M}$ & $<5 \mathrm{ppm}$ \\
\hline \multirow{3}{*}{$\begin{array}{l}\text { Within tank } \\
\text { headspace } \\
\text { (third set) }\end{array}$} & Flammable Gas & $\mathrm{CGM}$ & $0 \%$ of LFL \\
\hline & Organic Vapor & OVM & $0 \mathrm{ppm}$ \\
\hline & Ammonia & Draeger $^{\top \mathrm{M}}$ & $<5 \mathrm{ppm}$ \\
\hline
\end{tabular}

The results demonstrate that a flammable atmosphere was not present in the tank at the time of sampling.

\subsection{FLAMMABLE GAS MEASUREMENTS FOR TANK 241-ER-311}

Catch tank 241-ER-311 is located south of B-Plant in the 200 East Area. The tank is made of stainless steel and has a maximum capacity of $17,682 \mathrm{gal}$. It receives drainage from the 241 -ER151 and 241-ER-152 diversion boxes (Palit 1996). The tank has no high-efficiency particulate air (HEPA) filtration system and is vented by means of floor drains to the diversion boxes (CHG 2000a).

Flammable gas measurements for tank 241-ER-311 were started on November 1, 1999. At the time of sampling, the tank contained approximately 7,400 gal of waste. Combustible gas meter readings taken in the East riser and the tank headspace indicated a flammable gas concentration above the LFL for hydrogen in air. Three SUMMA ${ }^{2}$ canisters and one Hoke ${ }^{3}$ sample were taken in accordance with the work package. Preliminary results for the Hoke ${ }^{\mathrm{TM}}$ sample were issued on

${ }^{2}$ SUMMA is a trademark of Moletrics of Cleveland, Ohio.

${ }^{3}$ Hoke is a trademark of Hoke Incorporated, Cresskill, New Jersey. 


\section{RPP-7022 Rev: 0}

November 2, 1999. Hydrogen concentration was reported at 16.3 mole percent, approximately 4 times higher than the LFL. In response to the high CGM readings and Hoke ${ }^{\mathrm{TM}}$ results, the Tank Farm Contractor established a multi-discipline team to understand and mitigate the conditions found in the tank. Actions and conclusions reached by the team are discussed in RPP-5985, ER311 Flammable Gas Response and Findings (Dodd 2000). Sampling activities directed by the team are briefly discussed below.

Additional flammable gas readings and vapor samples were obtained through the East and West risers to monitor the hydrogen concentration in the tank. Vapor samples were also collected from piping and pits connected to the catch tank to assess the extent of the flammable gas condition. In addition, grab samples of the liquid waste were taken to determine the cause of the hydrogen generation and to allow transfer of the waste to a double-shell tank, if necessary. The Sampling and Analysis Plan for Catch Tank 241-ER-311 Vapor (Nguyen 1999a), Sampling and Analysis Plan for Catch Tank 241-ER-311 Waste (Nguyen 1999b), and Tank 241-ER-311 Interconnected Piping and Equipment Vapor Sampling and Analysis Plan (Sasaki 1999) were prepared for these sampling activities.

Based on the collected data and visual observations, the team concluded that the high level of hydrogen existed only in a small, almost airtight cylindrical column formed under the East riser. The isolated airspace was created when a plastic liner (i.e., pipe) inside the riser slipping to a lower position from its original location. In this lower position, one end of the liner rested on the bottom of the tank while the other end extended into the riser. The top of the riser was capped and the lower end of the liner was encased in the sludge on the bottom of the tank. The gap between the liner and the riser was then sealed by a build-up of solids, creating the isolated air space. It was postulated that the hydrogen in this isolated space was generated from radiolysis of water. Details of the actions taken by the team to understand and mitigate the flammable condition in tank 241-ER-311 are described in Dodd (2000).

Vapor sampling activities for tank 241-ER-311 are discussed in the following sections according to the sampling locations: East riser, West riser, and inter-connected equipment. Analytical results for liquid samples taken from the tank will be used for waste transfer (from 241-ER-311 to a double-shell tank). Liquid waste data is reported in HNF-1690, Tank 241-ER-311 Grab Samples, Analytical Results for the Final Report (Steen 2000).

\subsubsection{Vapor Sampling from Tank 241-ER-311 East Riser}

Combustible gas meter (CGM) readings, Hoke ${ }^{\mathrm{TM}}$, and SUMMA ${ }^{\mathrm{TM}}$ samples were collected from the East riser of catch tank 241-ER-311. On November 1, 1999, Hoke ${ }^{\text {TM }}$ and SUMMA ${ }^{\text {TM }}$ samples were collected after CGM readings indicated the present of a flammable gas above $100 \%$ of the LFL of hydrogen in air. Hoke ${ }^{T M}$ samples were analyzed for "permanent" (i.e., nonorganic) gases at the Pacific Northwest National Laboratory (PNNL). A Hoke ${ }^{\mathrm{TM}}$ sample is a small $(60-\mathrm{mL})$ metal cylinder. Its internal surfaces are not passivated; thus, results for some noninert gases may be biased low. However, Hoke ${ }^{\mathrm{TM}}$ results could be available shortly after sampling. SUMMA ${ }^{\mathrm{TM}}$ samples were analyzed at the Waste Sampling and Characterization Facility (WSCF) for both permanent and organic gases. A SUMMA ${ }^{\mathrm{TM}}$ sample is a large $(6,000-\mathrm{mL})$ metal container with passivated internal surfaces. In general, a larger, passivated 
sample container allows better sensitivity and accuracy. SUMMA ${ }^{\mathrm{TM}}$ samples must be radiologically screened prior to acceptance at WSCF; thus, SUMMA ${ }^{\mathrm{TM}}$ results could not be available as timely as the Hoke ${ }^{T M}$ results. For these reasons, a combination of Hoke ${ }^{T M}$ and SUMMA $^{\mathrm{TM}}$ samples was used to address data timeliness, accuracy, and sensitivity.

Laboratory results confirmed the presence of a flammable atmosphere within the riser. The flammable gases were identified as mainly hydrogen ( 3 to 4 times higher than the LFL) with a small amount of organics. On November 4, 1999, a CGM was used to monitor the hydrogen level in the tank. By the end of the day, CGM readings near the top of the riser were less than $25 \%$ of the LFL. On November 5, 1999, five Hoke ${ }^{T M}$ and three SUMMA ${ }^{T M}$ samples were collected. Hoke ${ }^{T M}$ samples were analyzed for permanent gases; SUMMA ${ }^{T M}$ samples were analyzed for permanent and organic gases. Hoke ${ }^{T M}$ results indicated a gradual increase in hydrogen concentration from the top of the riser to the bottom of the tank. Results at the 1-foot location (below top of riser) were less than detection limit while results at the 23-foot location were approximately $100 \%$ of the LFL. SUMMA ${ }^{T M}$ results also reflected this trend. Organic gases detected were mostly parafinic hydrocarbons at low concentrations. Combustible gas meter readings in the subsequent days detected no flammable gas.

Activities to collect flammable gas data from the East riser are summarized in Table 3-2. Hoke ${ }^{\mathrm{TM}}$ analytical results are reported in two letter reports from S. J Bos, PNNL, to J. S. Schofield (Bos 1999a and 1999b). SUMMA ${ }^{T M}$ results are reported in the Sampling and Analysis Data for Catch Tank 241-ER-311, Sampled November 1-10, 1999 (Stauffer 2000). A summary of the data is provided in Appendix A. Analytical techniques and uncertainty estimates for the data are provided in the references.

Table 3-2. Tank 241-ER-311 East Riser Vapor Sampling Activities. (2 Sheets)

\begin{tabular}{|c|c|c|c|}
\hline sompling & Bate Saringled & (1.6 & Descroptron or OMte \\
\hline \multirow[t]{2}{*}{ CGM } & $11 / 1 / 99$ & 3 and $23 \mathrm{ft}$ & $\begin{array}{l}\text { CGM pegged out at above } 100 \% \\
\text { LFL. }\end{array}$ \\
\hline & $11 / 4 / 99-11 / 10 / 99$ & $1 \mathrm{ft}$ & $\begin{array}{l}\text { CGM readings dropped below } \\
25 \% \text { LFL by the end of } 11 / 4 / 99 \text {. }\end{array}$ \\
\hline \multirow[t]{2}{*}{ Hoke $^{T M}$} & $11 / 1 / 99$ & $23 \mathrm{ft}$ & $\begin{array}{l}\text { Hydrogen concentration measured } \\
\text { at approximately } 400 \% \mathrm{LFL} \text {. }\end{array}$ \\
\hline & $11 / 5 / 99-11 / 6 / 99^{*}$ & $1,5,15,20$, and $23 \mathrm{ft}$ & $\begin{array}{l}\text { Hydrogen concentration changed } \\
\text { from less than detection limit to } \\
\text { approximately } 100 \% \text { LFL with } \\
\text { increasing depths. }\end{array}$ \\
\hline
\end{tabular}


RPP-7022 Rev. 0

Table 3-2. Tank 241-ER-311 East Riser Vapor Sampling Activities. (2 Sheets)

\begin{tabular}{|c|c|c|c|}
\hline Sanpling & Mate waingled: & 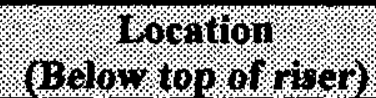 & Bescription of Brys. \\
\hline \multirow[t]{2}{*}{ SUMMA $^{\text {TM }}$} & $11 / 1 / 99$ & $23 \mathrm{ft}$ & $\begin{array}{l}\text { Hydrogen concentration measured } \\
\text { at approximately } 300 \% \text { LFL. } \\
\text { Organics detected were mostly } \\
\text { parafinic hydrocarbons. }\end{array}$ \\
\hline & $11 / 5 / 99-11 / 6 / 99$ & 1,15 , and $23 \mathrm{ft}$ & $\begin{array}{l}\text { Hydrogen concentrations changed } \\
\text { from } 0 \text { to } 72 \% \text { LFL with } \\
\text { increasing depths. Levels of } \\
\text { organics were much lower than } \\
\text { previously observed. }\end{array}$ \\
\hline
\end{tabular}

Notes:

$\left({ }^{*}\right)$ CGM readings were also taken at various depths during this sampling event.

\subsubsection{Vapor Sampling from Tank 241-ER-311 West Riser}

Hoke $^{T M}$ and SUMMA ${ }^{T M}$ samples were collected from the West riser on November 10, 1999. In addition, CGM readings were taken near the top of the riser. Hoke ${ }^{T M}$ samples were taken at 5 depths below the top of the riser: $1,5,15,20$, and 23 feet. SUMMA ${ }^{\top M}$ samples were taken at 3 depths: 1, 15, and 23 feet. Hydrogen was not detected in any Hoke ${ }^{\mathrm{TM}}$ or SUMMA ${ }^{\mathrm{TM}}$ sample. All organic results from the SUMMA ${ }^{T M}$ s were less than the detection limits.

Data collection activities are summarized in Table 3-3. Hoke ${ }^{\mathrm{TM}}$ analytical results are reported in a PNNL letter report from S. J. Bos to J. S. Schofield (Bos 1999c). SUMMA ${ }^{\text {TM }}$ results are reported in the Sampling and Analysis Data for Catch Tank 241-ER-311, Sampled November 1-10, 1999 (Stauffer 2000). A summary of the data is provided in Appendix A.

Table 3-3. Tank 241-ER-311 West Riser Vapor Sampling Activities

\begin{tabular}{|c|c|c|c|}
\hline sampling Y Ype & Oater Sinpled & (Below top or isen) & osscrintion of Gats \\
\hline Hoke $^{T M}$ & $11 / 10 / 99$ & $1,5,15,20$, and $23 \mathrm{ft}$ & $\begin{array}{l}\text { Hydrogen results were less than } \\
\text { detection limit. }\end{array}$ \\
\hline SUMMA ${ }^{\text {TM }}$ & $11 / 10 / 99$ & 1,15 , and $23 \mathrm{ft}$ & $\begin{array}{l}\text { All organic results were less than } \\
\text { detection limits. }\end{array}$ \\
\hline
\end{tabular}




\subsubsection{Vapor Sampling from Piping and Equipment Connected to Tank 241-ER-311}

Hoke $^{T M}$ samples and CGM readings were taken from piping and equipment connected to tank 241-ER-311 to determine the extent of the flammable gas condition. Hoke ${ }^{\mathrm{TM}}$ samples were taken at TR-1-EW, DRN-TR-2, TR-2-G, TR-1-CF, and 241-ER-151 diversion box and analyzed for permanent gases in accordance with Sasaki (1999). Figure 3-1 shows the sampling locations relative to $241-\mathrm{ER}-311$.

Data collection activities for the interconnected piping and equipment are summarized in Table 3-4. Analytical results are reported two PNNL letter reports from S. J Bos to J. S. Schofield (Bos 1999d and 1999e). The results indicated that a flammable gas atmosphere did not exist in the interconnected equipment by the sampling date. A summary of the data is provided in Appendix A.

Table 3-4. Vapor Sampling Activities for Piping and Equipment Connected to Tank 241-ER-311

\begin{tabular}{|c|c|c|c|}
\hline $80101194 \%$ & 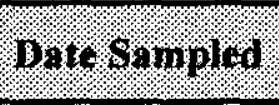 & (6) & 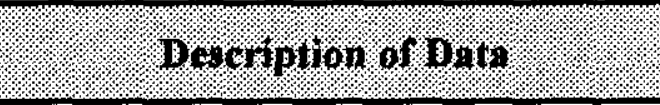 \\
\hline \multirow[t]{5}{*}{ Hoke $^{T M}$} & $11 / 6 / 99$ & TR-1-EW & $\begin{array}{l}\text { Hydrogen concentration was less than } \\
\text { detection limit }(0.001 \text { mole percent }) \text {. }\end{array}$ \\
\hline & $11 / 6 / 99$ & DRN-TR-2 & $\begin{array}{l}\text { Hydrogen concentration was less than } \\
\text { detection limit }(0.001 \text { mole percent }) \text {. }\end{array}$ \\
\hline & $11 / 8 / 99$ & TR-2-G & $\begin{array}{l}\text { Hydrogen concentration was less than } \\
\text { detection limit ( } 0.001 \text { mole percent). }\end{array}$ \\
\hline & $11 / 8 / 99$ & TR-1-CF & $\begin{array}{l}\text { Hydrogen concentration was less than } \\
\text { detection limit }(0.001 \text { mole percent }) \text {. }\end{array}$ \\
\hline & $11 / 9 / 99$ & 241-ER-151 & $\begin{array}{l}\text { Hydrogen concentration was less than } \\
\text { detection limit ( } 0.001 \text { mole percent). }\end{array}$ \\
\hline
\end{tabular}


RPP-7022 Rev. 0

Figure 3-1. Configuration of Catch Tank 241-ER-311 and Associated Equipment

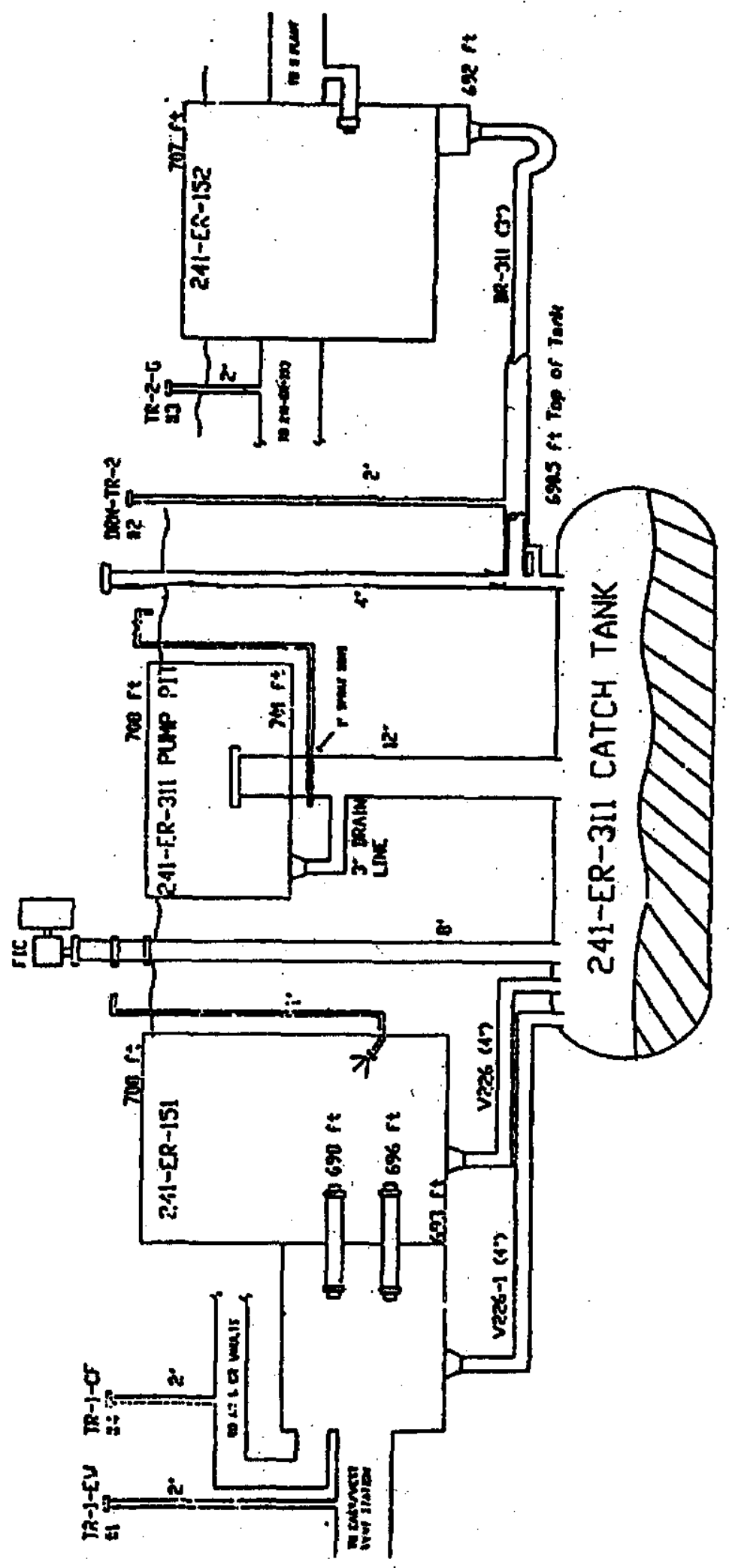




\subsection{FLAMMABLE GAS MEASUREMENTS FOR TANK 241-A-417}

Catch tank 241-A-417 is located within the A tank farm in the 200 East Area. The tank is a concrete vault with a welded carbon steel liner. It has a maximum capacity of 44,200 gal. At one time, the tank was used as a receiving vessel for process condensate and drainage from the 241-A complex. With the completion of the 702-AZ ventilation system, the tank receives only drainage from the 241-AX-501 valve pit (Palit 1996). The tank is no longer connected to the 241-AZ-702 Ventilation System and is vented through a HEPA filter.

Flammable gas measurements for catch tank 241-A-417 were performed on April 20, 2000. At the time of sampling, the tank contained approximately 12,300 gal of waste. Access to the tank headspace was through a dip tube (East dip tube). After turning off airflow going into the tank through the dip tubes, the measuring instruments (i.e., CGM, OVM, and Draeger ${ }^{T M}$ meter) were connected directly to the East dip tube. In effect, the dip tube was used as a sample tube to draw headspace gas from the tank. Since a riser was not involved, only readings of headspace gas drawn from the tank was needed. Measurements of combustible gas, organic vapor, and ammonia levels were to be repeated three times. However, because of a misunderstanding of the field directions, CGM readings were not repeated. Flammable gas level measurements for tank 241-A-417 are summarized in Table 3-5.

Table 3-5. Flammable Gas Measurements for Catch Tank 241-A-417

\begin{tabular}{|c|c|c|c|}
\hline Socation: & 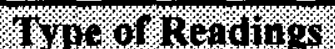 & 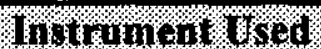 & Desilus \\
\hline \multirow{3}{*}{$\begin{array}{l}\text { Within tank headspace } \\
\text { (first set) }\end{array}$} & Flammable Gas & CGM & $0 \%$ of LFL \\
\hline & Organic Vapor & OVM & $0 \mathrm{ppm}$ \\
\hline & Ammonia & Draeger $^{\mathrm{TM}}$ & $<5 \mathrm{ppm}$ \\
\hline \multirow{3}{*}{$\begin{array}{l}\text { Within tank headspace } \\
\text { (second set) }\end{array}$} & Flammable Gas & CGM & Not Available \\
\hline & Organic Vapor & OVM & $0 \mathrm{ppm}$ \\
\hline & Ammonia & Draeger $^{\mathrm{TM}}$ & $<5 \mathrm{ppm}$ \\
\hline \multirow{3}{*}{$\begin{array}{c}\text { Within tank headspace } \\
\text { (third set) }\end{array}$} & Flammable Gas & CGM & Not Available \\
\hline & Organic Vapor & OVM & $0 \mathrm{ppm}$ \\
\hline & Ammonia & Draeger $^{\top M}$ & $<5 \mathrm{ppm}$ \\
\hline
\end{tabular}

Although the CGM reading was not repeated, it can be concluded that the tank contained no measurable concentrations of flammable gas at the time. 


\subsection{FLAMMABLE GAS MEASUREMENTS FOR TANK 241-EW-151}

Catch tank 241-EW-151 is located at the 241-EW-151 Vent Station (between 200 East and 200 West Areas). The tank is made of stainless steel and has a maximum capacity of 790 gal (Palit 1996). It is passively ventilated through a breather filter (CHG 2000a).

Flammable gas measurements and tracer gas injection for catch tank 241-EW-151 were performed on May 4 and 5, 2000. At the time, the tank contained approximately 350 gal of waste. Access to the tank headspace was through a riser on which the breather filter is situated. Combustible gas, organic vapor, and ammonia level measurements were taken at 1 and 12 feet below the top of the riser. The readings at the 12-foot depth were inside the tank headspace.

Tracer gas injection results are not available at this time. This section will be updated to include the data when it becomes available. Measurements of combustible gas, organic vapor, and ammonia levels were to be repeated three times at each location. However, because of a misunderstanding of the field directions, CGM readings were not repeated. Flammable gas measurements for tank 241-EW-151 are summarized in Table 3-6.

Table 3-6. Flammable Gas Measurements for Catch Tank 241-EW-151

\begin{tabular}{|c|c|c|c|}
\hline Yocallon: & Moe o h R cadings & Min trument Gser & Results. \\
\hline \multirow{3}{*}{$\begin{array}{l}\text { One foot below top of riser } \\
\text { (first set) }\end{array}$} & Flammable Gas & CGM & $0 \%$ of LFL \\
\hline & Organic Vapor & OVM & $0 \mathrm{ppm}$ \\
\hline & Ammonia & Draeger $^{T M}$ & $<5 \mathrm{ppm}$ \\
\hline \multirow{3}{*}{$\begin{array}{l}\text { One foot below top of riser } \\
\text { (second set) }\end{array}$} & Flammable Gas & CGM & Not Available \\
\hline & Organic Vapor & OVM & $0 \mathrm{ppm}$ \\
\hline & Ammonia & Draeger ${ }^{T M}$ & $<5 \mathrm{ppm}$ \\
\hline \multirow{3}{*}{$\begin{array}{l}\text { One foot below top of riser } \\
\text { (third set) }\end{array}$} & Flammable Gas & CGM & Not Available \\
\hline & Organic Vapor & OVM & $0 \mathrm{ppm}$ \\
\hline & Ammonia & Draeger $^{\mathrm{TM}}$ & $<5 \mathrm{ppm}$ \\
\hline \multirow{3}{*}{$\begin{array}{l}\text { Within tank headspace } \\
\text { (first set) }\end{array}$} & Flammable Gas & $\mathrm{CGM}$ & $0 \%$ of LFL \\
\hline & Organic Vapor & $\mathrm{OVM}$ & $0 \mathrm{ppm}$ \\
\hline & Ammonia & Draeger $^{T M}$ & $<5 \mathrm{ppm}$ \\
\hline \multirow{3}{*}{$\begin{array}{l}\text { Within tank headspace } \\
\text { (second set) }\end{array}$} & Flammable Gas & CGM & Not Available \\
\hline & Organic Vapor & $\mathrm{OVM}$ & $0 \mathrm{ppm}$ \\
\hline & Ammonia & Draeger $^{\top \mathrm{M}}$ & $<5$ ppm \\
\hline \multirow{3}{*}{$\begin{array}{l}\text { Within tank headspace } \\
\text { (third set) }\end{array}$} & Flammable Gas & CGM & Not Available \\
\hline & Organic Vapor & OVM & $0 \mathrm{ppm}$ \\
\hline & Ammonia & Draeger $^{T M}$ & $<5 \mathrm{ppm}$ \\
\hline
\end{tabular}

Although CGM reading at each location was not repeated, it can be concluded that a flammable atmosphere did not exist in the tank headspace nor the riser at the time of sampling. 


\subsection{FLAMMABLE GAS MEASUREMENTS FOR TANK 241-A-302A}

Catch tank 241-A-302A is located south of the PUREX facility in the 200 East Area. The tank is made of carbon steel and has a maximum capacity of $8438 \mathrm{gal}$. It receives drainage from the 241-A-151 diversion box (Palit 1996). It is vented through a HEPA filter.

Flammable gas measurements for catch tank 241-A-302A were performed on May 24, 2000. At that time, the tank contained approximately 930 gal of waste. Access to the tank headspace was through a riser on which an $\mathrm{ENRAF}^{4}$ is situated (ENRAF ${ }^{\mathrm{TM}}$ is a liquid level measurement device). Combustible gas, organic vapor, and ammonia level measurements were taken at 1 and 21.5 feet below the top of the riser. Readings at the 21.5-foot depth were inside the tank headspace. Measurements of combustible gas, organic vapor, and ammonia levels were to be repeated three times at each location. However, because of a misunderstanding of the field directions, CGM readings were not repeated. Flammable gas measurements for tank 241-A$302 \mathrm{~A}$ are summarized in Table 3-7.

Table 3-7. Flammable Gas Measurements for Catch Tank 241-A-302A

\begin{tabular}{|c|c|c|c|}
\hline Todatou & W a. or Rordurat & What runcur Used & Restius \\
\hline \multirow{3}{*}{$\begin{array}{l}\text { One foot below top of riser } \\
\text { (first set) }\end{array}$} & Flammable Gas & $\mathrm{CGM}$ & $0 \%$ of LFL \\
\hline & Organic Vapor & OVM & $6 \mathrm{ppm}$ \\
\hline & Ammonia & Draeger $^{\top M}$ & $50 \mathrm{ppm}$ \\
\hline \multirow{3}{*}{$\begin{array}{l}\text { One foot below top of riser } \\
\text { (second set) }\end{array}$} & Flammable Gas & $\mathrm{CGM}$ & Not Available \\
\hline & Organic Vapor & OVM & $5 \mathrm{ppm}$ \\
\hline & Ammonia & Draeger $^{\mathrm{TM}}$ & $50 \mathrm{ppm}$ \\
\hline \multirow{3}{*}{$\begin{array}{l}\text { One foot below top of riser } \\
\text { (third set) }\end{array}$} & Flammable Gas & $\mathrm{CGM}$ & Not Available \\
\hline & Organic Vapor & OVM & $5 \mathrm{ppm}$ \\
\hline & Ammonia & Draeger $^{\mathrm{TM}}$ & $50 \mathrm{ppm}$ \\
\hline \multirow{3}{*}{$\begin{array}{l}\text { Within tank headspace } \\
\text { (first set) }\end{array}$} & Flammable Gas & CGM & $0 \%$ of LFL \\
\hline & Organic Vapor & OVM & $4.3 \mathrm{ppm}$ \\
\hline & Ammonia & Draeger $^{\mathrm{TM}}$ & $40 \mathrm{ppm}$ \\
\hline \multirow{3}{*}{$\begin{array}{l}\text { Within tank headspace } \\
\text { (second set) }\end{array}$} & Flammable Gas & CGM & Not Available \\
\hline & Organic Vapor & OVM & $4.3 \mathrm{ppm}$ \\
\hline & Ammonia & Draeger $^{\mathrm{TM}}$ & $40 \mathrm{ppm}$ \\
\hline \multirow{3}{*}{$\begin{array}{l}\text { Within tank headspace } \\
\text { (third set) }\end{array}$} & Flammable Gas & CGM & Not Available \\
\hline & Organic Vapor & OVM & $4.8 \mathrm{ppm}$ \\
\hline & Ammonia & Draeger $^{\mathrm{TM}}$ & $40 \mathrm{ppm}$ \\
\hline
\end{tabular}

${ }^{4} \mathrm{ENRAF}$ is a trademark of the ENRAF Corporation, Houston, Texas 
Although detectable levels of organic vapor and ammonia were observed, it can be concluded that a flammable atmosphere did not exist in the tank headspace nor riser at the time of sampling.

\subsection{FLAMMABLE GAS MEASUREMENTS FOR TANK 241-UX-302A}

Catch tank 241-UX-302A is located east of U Plant in the 200 West Area. The tank is made of carbon steel and has a maximum capacity of 17,682 gal. It receives drainage from the 241-UX-154 diversion box and precipitation collected through the 291-U stack and encasement (Palit 1996). It has no HEPA filtration system and is vented by means of the floor drain to the diversion box (CHG 2000a).

Flammable gas measurements for catch tank 241-UX-302A were performed on June 15, 2000. At that time, the tank contained approximately 2,750 gal of waste. Access to the tank headspace was through a riser on which an ENRAFTM is situated. Combustible gas, organic vapor, and ammonia level measurements were taken at 1 and 24 feet below the top of the riser. Readings at the 24-foot depth were inside the tank headspace. Measurements of combustible gas, organic vapor, and ammonia levels were repeated three times at each location. Flammable gas measurements for tank 241-UX-302A are summarized in Table 3-8.

Table 3-8. Flammable Gas Measurements for Catch Tank 241-UX-302A

\begin{tabular}{|c|c|c|c|}
\hline Tocanion & Troe or Readings & Tistruncan Voed & Resulus \\
\hline \multirow{3}{*}{$\begin{array}{l}\text { One foot below top of riser } \\
\text { (first set) }\end{array}$} & Flammable Gas & CGM & $0 \%$ of LFL \\
\hline & Organic Vapor & OVM & $0.4 \mathrm{ppm}$ \\
\hline & Ammonia & Draeger $^{\mathrm{TM}}$ & $<5 \mathrm{ppm}$ \\
\hline \multirow{3}{*}{$\begin{array}{l}\text { One foot below top of riser } \\
\text { (second set) }\end{array}$} & Flammable Gas & CGM & $0 \%$ of LFL \\
\hline & Organic Vapor & OVM & $0.3 \mathrm{ppm}$ \\
\hline & Ammonia & Draeger $^{\mathrm{TM}}$ & $<5 \mathrm{ppm}$ \\
\hline \multirow{3}{*}{$\begin{array}{l}\text { One foot below top of riser } \\
\text { (third set) }\end{array}$} & Flammable Gas & CGM & $0 \%$ of LFL \\
\hline & Organic Vapor & OVM & $0.4 \mathrm{ppm}$ \\
\hline & Ammonia & Draeger $^{T M}$ & $<5 \mathrm{ppm}$ \\
\hline \multirow{3}{*}{$\begin{array}{l}\text { Within tank headspace } \\
\text { (first set) }\end{array}$} & Flammable Gas & CGM & $0 \%$ of LFL \\
\hline & Organic Vapor & OVM & $0.4 \mathrm{ppm}$ \\
\hline & Ammonia & Draeger ${ }^{\top \mathrm{M}}$ & $<5 \mathrm{ppm}$ \\
\hline \multirow{3}{*}{$\begin{array}{l}\text { Within tank headspace } \\
\text { (second set) }\end{array}$} & Flammable Gas & CGM & $0 \%$ of LFL \\
\hline & Organic Vapor & OVM & $0.4 \mathrm{ppm}$ \\
\hline & Ammonia & Draeger $^{\mathrm{TM}}$ & $<5 \mathrm{ppm}$ \\
\hline \multirow{3}{*}{$\begin{array}{l}\text { Within tank headspace } \\
\text { (third set) }\end{array}$} & Flammable Gas & CGM & $0 \%$ of LFL \\
\hline & Organic Vapor & OVM & $0.4 \mathrm{ppm}$ \\
\hline & Ammonia & Draeger $^{\top \mathrm{M}}$ & $<5 \mathrm{ppm}$ \\
\hline
\end{tabular}


The results demonstrate that a flammable atmosphere was not present in the tank at the time of sampling.

\subsection{FLAMMABLE GAS MEASUREMENTS FOR TANK 241-U-301B}

Catch tank 241-U-301B is located in the southwest corner of the U tank farm in the 200 West Area. The tank is an unlined cylindrical concrete vault and has a maximum capacity of $35,275 \mathrm{gal}$. It receives drainage from the $241-\mathrm{U}-151,241-\mathrm{U}-152$, and $241-\mathrm{U}-153$ diversion boxes (Palit 1996). The tank has no HEPA filtration system and is vented by means of the floor drains to the diversion boxes (CHG 2000a).

Flammable gas measurements for catch tank 241-U-301B were performed on June 15, 2000. At the time, the tank contained approximately $8,000 \mathrm{gal}$ of waste. Access to the tank headspace was through a riser on which an ENRAF ${ }^{\mathrm{TM}}$ is situated. Combustible gas, organic vapor, and ammonia level measurements were taken at 1 and 23 feet below the top of the riser. Readings at the 23foot depth were inside the tank headspace. Measurements of combustible gas, organic vapor, and ammonia levels were repeated three times at each location. Flammable gas measurements for tank 241-U-301B are summarized in Table 3-9.

Table 3-9. Flammable Gas Measurements for Catch Tank 241-U-301B

\begin{tabular}{|c|c|c|c|}
\hline 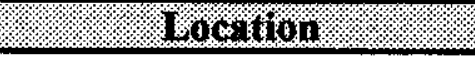 & Whos or Roradun & 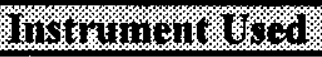 & Rrosiul 1 \\
\hline \multirow{3}{*}{$\begin{array}{l}\text { One foot below top of riser } \\
\text { (first set) }\end{array}$} & Flammable Gas & CGM & $0 \%$ of LFL \\
\hline & Organic Vapor & OVM & $0 \mathrm{ppm}$ \\
\hline & Ammonia & Draeger $^{\mathrm{TM}}$ & $<5 \mathrm{ppm}$ \\
\hline \multirow{3}{*}{$\begin{array}{l}\text { One foot below top of riser } \\
\text { (second set) }\end{array}$} & Flammable Gas & CGM & $0 \%$ of LFL \\
\hline & Organic Vapor & OVM & $0 \mathrm{ppm}$ \\
\hline & Ammonia & Draeger $^{\top M}$ & $<5 \mathrm{ppm}$ \\
\hline \multirow{3}{*}{$\begin{array}{l}\text { One foot below top of riser } \\
\text { (third set) }\end{array}$} & Flammable Gas & CGM & $0 \%$ of LFL \\
\hline & Organic Vapor & OVM & $0 \mathrm{ppm}$ \\
\hline & Ammonia & Draeger $^{\mathrm{TM}}$ & $<5 \mathrm{ppm}$ \\
\hline \multirow{3}{*}{$\begin{array}{l}\text { Within tank headspace } \\
\text { (first set) }\end{array}$} & Flammable Gas & CGM & $0 \%$ of LFL \\
\hline & Organic Vapor & OVM & $0 \mathrm{ppm}$ \\
\hline & Ammonia & Draeger $^{T M}$ & $<5 \mathrm{ppm}$ \\
\hline \multirow{3}{*}{$\begin{array}{l}\text { Within tank headspace } \\
\text { (second set) }\end{array}$} & Flammable Gas & CGM & $0 \%$ of LFL \\
\hline & Organic Vapor & OVM & $0 \mathrm{ppm}$ \\
\hline & Ammonia & Draeger $^{\mathrm{TM}}$ & $<5 \mathrm{ppm}$ \\
\hline \multirow{3}{*}{$\begin{array}{c}\text { Within tank headspace } \\
\text { (third set) }\end{array}$} & Flammable Gas & CGM & $0 \%$ of LFL \\
\hline & Organic Vapor & OVM & $0 \mathrm{ppm}$ \\
\hline & Ammonia & Draeger $^{\top M}$ & $<5 \mathrm{ppm}$ \\
\hline
\end{tabular}


The results demonstrate that a flammable atmosphere was not present in the tank at the time of sampling.

\subsection{FLAMMABLE GAS MEASUREMENTS FOR TANK 241-TX-302C}

Catch tank 241-TX-302C is located east of T-Plant in the 200 West Area. The tank is made of carbon steel and has a maximum capacity of $17,681 \mathrm{gal}$. It receives drainage from the 241-TX-154 diversion box (Palit 1996). The tank has no HEPA filtration system and is vented by means of the floor drain to the diversion box (CHG 2000a).

Flammable gas measurements for catch tank 241-TX-302C were performed on July 20, 2000. At the time, the tank contained approximately $160 \mathrm{gal}$ of waste. Access to the tank headspace was through a riser on which an ENRAF ${ }^{\mathrm{TM}}$ is situated. Combustible gas, organic vapor, and ammonia level measurements were taken at 1 and 32 feet below the top of the riser. Readings at the 32foot depth were inside the tank headspace. Measurements of combustible gas, organic vapor, and ammonia levels were repeated three times at each location. Flammable gas measurements for tank 241-TX-302C are summarized in Table 3-10.

Table 3-10. Flammable Gas Measurements for Catch Tank 241-TX-302C

\begin{tabular}{|c|c|c|c|}
\hline 60011010 & 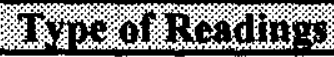 & 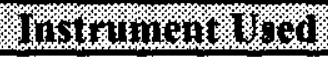 & Rosilo \\
\hline \multirow{3}{*}{$\begin{array}{l}\text { One foot below top of riser } \\
\text { (first set) }\end{array}$} & Flammable Gas & CGM & $0 \%$ of LFL \\
\hline & Organic Vapor & OVM & $1 \mathrm{ppm}$ \\
\hline & Ammonia & Draeger $^{\mathrm{TM}}$ & $<5 \mathrm{ppm}$ \\
\hline \multirow{3}{*}{$\begin{array}{l}\text { One foot below top of riser } \\
\text { (second set) }\end{array}$} & Flammable Gas & CGM & $0 \%$ of LFL \\
\hline & Organic Vapor & OVM & $0.9 \mathrm{ppm}$ \\
\hline & Ammonia & Draeger $^{\mathrm{TM}}$ & $<5 \mathrm{ppm}$ \\
\hline \multirow{3}{*}{$\begin{array}{l}\text { One foot below top of riser } \\
\text { (third set) }\end{array}$} & Flammable Gas & CGM & $0 \%$ of LFL \\
\hline & Organic Vapor & OVM & $0.6 \mathrm{ppm}$ \\
\hline & Ammonia & Draeger $^{\top M}$ & $<5 \mathrm{ppm}$ \\
\hline \multirow{3}{*}{$\begin{array}{l}\text { Within tank headspace } \\
\text { (first set) }\end{array}$} & Flammable Gas & CGM & $0 \%$ of LFL \\
\hline & Organic Vapor & $\mathrm{OVM}$ & $1 \mathrm{ppm}$ \\
\hline & Ammonia & Draeger $^{\top M}$ & $<5 \mathrm{ppm}$ \\
\hline \multirow{3}{*}{$\begin{array}{l}\text { Within tank headspace } \\
\text { (second set) }\end{array}$} & Flammable Gas & $\overline{C G M}$ & $0 \%$ of LFL \\
\hline & Organic Vapor & OVM & $1 \mathrm{ppm}$ \\
\hline & Ammonia & Draeger $^{\mathrm{TM}}$ & $<5 \mathrm{ppm}$ \\
\hline \multirow{3}{*}{$\begin{array}{l}\text { Within tank headspace } \\
\text { (third set) }\end{array}$} & Flammable Gas & CGM & $0 \%$ of LFL \\
\hline & Organic Vapor & OVM & $1 \mathrm{ppm}$ \\
\hline & Ammonia & Draeger $^{T M}$ & $<5 \mathrm{ppm}$ \\
\hline
\end{tabular}

The results demonstrate that a flammable atmosphere was not present in the tank at the time of sampling. 


\subsection{FLAMMABLE GAS MEASUREMENTS FOR TANK 241-AZ-151}

Catch tank $241-\mathrm{AZ}-151$ is located within the $\mathrm{AZ}$ tank farm in the 200 East Area. The tank is a concrete vault with a carbon steel liner. It has a maximum capacity of $11,900 \mathrm{gal}$. The tank receives drainage from the 241-AZ-101 and 241-AZ-102 vent header seal loops, AZ tank farm leak detection pits, 241-AZ-801 A instrumentation building floor drain, and 241-AZ-152 sluicing transfer box floor drain (Palit 1996). It has no HEPA filtration system and is vented indirectly through waste transfer lines (CHG 2000a).

Flammable gas measurements for catch tank 241-AZ-151 were performed on July 25, 2000. At the time, the tank contained approximately $700 \mathrm{gal}$ of waste. Access to the tank headspace was through a riser on which an ENRAF ${ }^{T M}$ is situated. Combustible gas, organic vapor, and ammonia level measurements were taken at 1 and 19 feet below the top of the riser. Readings at the 19foot depth were inside the tank headspace. Measurements of combustible gas, organic vapor, and ammonia levels were repeated three times at each location. Flammable gas measurements for tank 241-AZ-151 are summarized in Table 3-11.

Table 3-11. Flammable Gas Measurements for Catch Tank 241-AZ-151

\begin{tabular}{|c|c|c|c|}
\hline Location & Type or Readings & Instrument Used & Results \\
\hline \multirow{3}{*}{$\begin{array}{l}\text { One foot below top of riser } \\
\text { (first set) }\end{array}$} & Flammable Gas & $\mathrm{CGM}$ & $0 \%$ of LFL \\
\hline & Organic Vapor & $\overline{\mathrm{OVM}}$ & $0.6 \mathrm{ppm}$ \\
\hline & Ammonia & Draeger $^{T M}$ & $<5 \mathrm{ppm}$ \\
\hline \multirow{3}{*}{$\begin{array}{l}\text { One foot below top of riser } \\
\text { (second set) }\end{array}$} & Flammable Gas & CGM & $0 \%$ of LFL \\
\hline & Organic Vapor & OVM & $1.3 \mathrm{ppm}$ \\
\hline & Ammonia & Draeger $^{\mathrm{TM}}$ & $<5 \mathrm{ppm}$ \\
\hline \multirow{3}{*}{$\begin{array}{l}\text { One foot below top of riser } \\
\text { (third set) }\end{array}$} & Flammable Gas & CGM & $0 \%$ of LFL \\
\hline & Organic Vapor & OVM & $0.6 \mathrm{ppm}$ \\
\hline & Ammonia & Draeger $^{T M}$ & $<5 \mathrm{ppm}$ \\
\hline \multirow{3}{*}{$\begin{array}{l}\text { Within tank headspace } \\
\text { (first set) }\end{array}$} & Flammable Gas & $\mathrm{CGM}$ & $0 \%$ of LFL \\
\hline & Organic Vapor & OVM & $1.5 \mathrm{ppm}$ \\
\hline & Ammonia & Draeger $^{\top M}$ & $<5 \mathrm{ppm}$ \\
\hline \multirow{3}{*}{$\begin{array}{l}\text { Within tank headspace } \\
\text { (second set) }\end{array}$} & Flammable Gas & $\mathrm{CGM}$ & $0 \%$ of LFL \\
\hline & Organic Vapor & OVM & $1.5 \mathrm{ppm}$ \\
\hline & Ammonia & Draeger ${ }^{T M}$ & $<5 \mathrm{ppm}$ \\
\hline \multirow{3}{*}{$\begin{array}{c}\text { Within tank headspace } \\
\text { (third set) }\end{array}$} & Flammable Gas & $\mathrm{CGM}$ & $0 \%$ of LFL \\
\hline & Organic Vapor & OVM & $1.7 \mathrm{ppm}$ \\
\hline & Ammonia & Draeger $^{\mathrm{TM}}$ & $<5 \mathrm{ppm}$ \\
\hline
\end{tabular}

The results demonstrate that a flammable atmosphere was not present in the tank at the time of sampling. 


\subsection{FLAMMABLE GAS MEASUREMENTS FOR TANK 241-AZ-154}

Catch tank 24l-AZ-154 is located within the AZ tank farm in the 200 East Area. The tank is a concrete vault with a carbon steel liner. It has a maximum capacity of $869 \mathrm{gal}$. It is used to collect condensate from the 241-AY and 241-AZ in-tank steam heating coils. The coils have not been used for years, and daily liquid level monitoring in the catch tank reveals zero reading (Palit 1996). It has no HEPA filtration system and is vented indirectly through waste transfer lines (CHG 2000a).

Flammable gas measurements for catch tank 241-AZ-154 were performed on August 15, 2000. The tank was nearly empty at the time of sampling. A special sampling probe was fabricated to allow the probe to enter a riser at ground level, through the floor drain of the pump pit located above the tank, and into the headspace of the tank. Combustible gas, organic vapor, and ammonia level measurements were taken at 1 and 12 feet below ground level. Readings at the 1foot and 12-foot depths were inside the pump pit and the catch tank headspace, respectively. Measurements of combustible gas, organic vapor, and ammonia levels were repeated three times at each location. Flammable gas measurements for tank 241-AZ-154 are summarized in Table 312.

Table 3-12. Flammable Gas Measurements for Catch Tank 241-AZ-154

\begin{tabular}{|c|c|c|c|}
\hline Eocation & Type of Readings & Instrument Used & Results \\
\hline \multirow{3}{*}{$\begin{array}{l}\text { One foot below top of riser } \\
\text { (first set) }\end{array}$} & Flammable Gas & CGM & $0 \%$ of LFL \\
\hline & Organic Vapor & $\mathrm{OVM}$ & $0 \mathrm{ppm}$ \\
\hline & Ammonia & Draeger ${ }^{\mathrm{TM}}$ & $<5 \mathrm{ppm}$ \\
\hline \multirow{3}{*}{$\begin{array}{l}\text { One foot below top of riser } \\
\text { (second set) }\end{array}$} & Flammable Gas & $\mathrm{CGM}$ & $0 \%$ of LFL \\
\hline & Organic Vapor & OVM & $0 \mathrm{ppm}$ \\
\hline & Ammonia & Draeger ${ }^{T M}$ & $<5 \mathrm{ppm}$ \\
\hline \multirow{3}{*}{$\begin{array}{l}\text { One foot below top of riser } \\
\text { (third set) }\end{array}$} & Flammable Gas & $\mathrm{CGM}$ & $0 \%$ of LFL \\
\hline & Organic Vapor & OVM & $0 \mathrm{ppm}$ \\
\hline & Ammonia & Draeger ${ }^{\mathrm{TM}}$ & $<5 \mathrm{ppm}$ \\
\hline \multirow{3}{*}{$\begin{array}{l}\text { Within tank headspace } \\
\text { (first set) }\end{array}$} & Flammable Gas & CGM & $0 \%$ of LFL \\
\hline & Organic Vapor & OVM & $0 \mathrm{ppm}$ \\
\hline & Ammonia & Draeger & $<5 \mathrm{ppm}$ \\
\hline \multirow{3}{*}{$\begin{array}{l}\text { Within tank headspace } \\
\text { (second set) }\end{array}$} & Flammable Gas & $\mathrm{CGM}$ & $0 \%$ of LFL \\
\hline & Organic Vapor & $\mathrm{OVM}$ & $0 \mathrm{ppm}$ \\
\hline & Ammonia & Draeger ${ }^{T M}$ & $<5 \mathrm{ppm}$ \\
\hline \multirow{3}{*}{$\begin{array}{l}\text { Within tank headspace } \\
\text { (third set) }\end{array}$} & Flammable Gas & $\mathrm{CGM}$ & $0 \%$ of LFL \\
\hline & Organic Vapor & OVM & $0 \mathrm{ppm}$ \\
\hline & Ammonia & Draeger $\overline{T M}$ & $<5 \mathrm{ppm}$ \\
\hline
\end{tabular}

The results demonstrate that a flammable atmosphere was not present in the tank at the time of sampling. 


\subsection{FLAMMABLE GAS MEASUREMENTS FOR TANK 241-A-350}

Catch tank 241-A-350 was built as part of the 24l-A-350 lift station and is located within the A tank farm in the 200 East Area. The tank is made of stainless steel and has a maximum capacity of $776 \mathrm{gal}$. It receives drainage from the A tank farm complex through the 241-A-A and -B valve pits and 241-A cleanout boxes (Palit 1996). The tank has no ventilation system or breather filter and is indirectly ventilated through waste transfer lines (CHG 2000a).

Flammable gas measurements and tracer gas injection for catch tank 241-A-350 were performed on August 29 and 30, 2000. At the time, the tank contained approximately 350 gal of waste. Access to the tank headspace was through a dip tube. Similar to catch tank 241-A-417, only measurements inside the tank headspace were obtained.

Tracer gas injection results are not available at this time. This section will be updated to include the data when it becomes available. Measurements of combustible gas, organic vapor, and ammonia levels were repeated three times. Results are shown in Table 3-13.

Table 3-13. Flammable Gas Measurements for Catch Tank 241-A-350

\begin{tabular}{|c|c|c|c|}
\hline Wocation & Yypo of Readings & Instrument Used & Results \\
\hline \multirow{3}{*}{$\begin{array}{l}\text { Within tank headspace } \\
\text { (first set) }\end{array}$} & Flammable Gas & CGM & $0 \%$ of LFL \\
\hline & Organic Vapor & OVM & $1.2 \mathrm{ppm}$ \\
\hline & Ammonia & Draeger $^{\mathrm{TM}}$ & $<5 \mathrm{ppm}$ \\
\hline \multirow{3}{*}{$\begin{array}{l}\text { Within tank headspace } \\
\text { (second set) }\end{array}$} & Flammable Gas & $\mathrm{CGM}$ & $0 \%$ of LFL \\
\hline & Organic Vapor & OVM & $1.2 \mathrm{ppm}$ \\
\hline & Ammonia & Draeger $^{\mathrm{TM}}$ & $<5 \mathrm{ppm}$ \\
\hline \multirow{3}{*}{$\begin{array}{l}\text { Within tank headspace } \\
\text { (third set) }\end{array}$} & Flammable Gas & CGM & $0 \%$ of LFL \\
\hline & Organic Vapor & OVM & $1.2 \mathrm{ppm}$ \\
\hline & Ammonia & Draeger $^{\mathrm{TM}}$ & $<5$ ppm \\
\hline
\end{tabular}

The results demonstrate that a flammable atmosphere was not present in the tank at the time of sampling. 


\subsection{FLAMMABLE GAS MEASUREMENTS FOR TANK 204-AR-TK-1}

Catch tank 204-AR-TK-1 is located in the 204-AR Waste Unloading Facility in the 200 East Area. The tank is made of stainless steel and has a maximum capacity of $1500 \mathrm{gal}$. It is used to catch potential railcar leaks through the floor drain system. The tank is actively vented by the facility ventilation system (Palit 1996).

Flammable gas measurements for catch tank 204-AR-TK-1 were taken on September 18, 2000. At the time, the tank contained approximately 500 gal of waste. Measurements were taken through a port in an exhaust duct of the tank. Flammable gas concentrations at this location would be equivalent to those in the tank headspace because airflow through the tank is very high. (Air flow in the ventilation duct is maintained at approximately 10 cubic feet per minute).

Measurements of combustible gas, organic vapor, and ammonia levels were repeated three times. Results are shown in Table 3-14.

Table 3-14. Flammable Gas Measurements for Catch Tank 204-AR-TK-1

\begin{tabular}{|c|c|c|c|}
\hline Gocation & Type or Readings & Instrument Used & Results \\
\hline \multirow{3}{*}{$\begin{array}{l}\text { Within tank headspace } \\
\text { (first set) }\end{array}$} & Flammable Gas & CGM & $0 \%$ of LFL \\
\hline & Organic Vapor & OVM & $0 \mathrm{ppm}$ \\
\hline & Ammonia & Draeger $^{\mathrm{TM}}$ & $<5 \mathrm{ppm}$ \\
\hline \multirow{3}{*}{$\begin{array}{l}\text { Within tank headspace } \\
\text { (second set) }\end{array}$} & Flammable Gas & CGM & $0 \%$ of LFL \\
\hline & Organic Vapor & OVM & $0 \mathrm{ppm}$ \\
\hline & Ammonia & Draeger $^{\top M}$ & $<5 \mathrm{ppm}$ \\
\hline \multirow{3}{*}{$\begin{array}{c}\text { Within tank headspace } \\
\text { (third set) }\end{array}$} & Flammable Gas & CGM & $0 \%$ of LFL \\
\hline & Organic Vapor & OVM & $0 \mathrm{ppm}$ \\
\hline & Ammonia & Draeger $^{T M}$ & $<5 \mathrm{ppm}$ \\
\hline
\end{tabular}

The results demonstrate that a flammable atmosphere was not present in the tank at the time of sampling. 
RPP-7022 Rev. 0

\subsection{SUMMARY AND RECOMMENDATIONS}

With the exception of tank 241-ER-311, vapor sampling results show that flammable conditions did not exist in the RPP catch tanks at the time of sampling. A flammable atmosphere existed in the East riser of tank 241-ER-311 only because a series of events and conditions contributed to the making of a small, isolated space. These events and conditions include:

- The plastic liner was disconnected and allowed to fall into the tank;

- The length of the liner and the depth of the tank were such that the lower end of the liner was in the sludge and the upper part of the liner extended into the riser;

- The gap between the liner and riser was probably sealed by a build-up of solids, and

- The sludge below the riser contained a significant amount of strontium-90 that can hydrolyze water to generate hydrogen at a high rate.

The plastic liner was removed from the tank on January 21, 2000. Removal of the liner eliminated the conditions that contributed to the isolated zone. Tank 241-ER-311 is not expected to contain a flammable atmosphere in the current configuration. Overall, results of the catch tank vapor sampling indicate that the RPP active catch tanks are unlikely to contain high concentrations of a flammable gas.

Based on the catch tank vapor sampling effort, it is recommended that the following be considered in future vapor sampling of other miscellaneous waste storage tanks:

- Concentrations of flammable gases in waste storage tanks are due to accumulation over time. Factors determining accumulation rate include gas generation and ventilation rates.

Gas generation rate is determined by the volume and chemical/radiological characteristics of the waste. The contents of RPP catch tanks vary over time because they are actively used. Waste is being received and transferred out of the tanks as part of tank farm operations. Most of the tanks are not actively ventilated. Ventilation rates in these tanks vary according to changes in atmospheric conditions (i.e., temperature and pressure). If more definitive data are needed, effects of changes in tank contents and ventilation rate should be evaluated.

- The Tank Safety Screening Data Quality Objectives (Dukelow et al. 1995) specifies vapor sampling requirements if a flammable gas concentration exceeding $25 \%$ of the LFL is encountered. However, the described 241-ER-311 experience indicates that additional actions (and timeline for such actions) are needed when a flammable atmosphere is discovered. These actions should address personnel safety, additional vapor and waste characterization, monitoring, and hazard mitigation. The DQO should be revised or a new DQO specific to the vapor sampling be prepared prior to sampling. At a minimum, the DQO should include guidelines provided in HNF-IP-1266, Chapter 5.11, Attachment A, "Emergency Action and Recovery Activity Guidelines" (LMHC 2000).

- A potential mitigation action, implemented after the tank 241-ER-311 experience, was to install a temporary HEPA filter on an unventilated tank if a flammable atmosphere is discovered. For tanks with no filtered ventilation, an air emissions Notice of 
RPP-7022 Rev. 0

Construction (NOC) may be required for installation of a HEPA filter. An NOC should be obtained during the planning phase to avoid possible delays. 
RPP-7022 Rev. 0

\subsection{REFERENCES}

Bos, S. J., 1999a, Untitled memorandum to J. S. Schofield, LMHC, dated November 3, Pacific Northwest National Laboratory, Richland, Washington.

Bos, S. J., 1999b, Untitled memorandum to J. S. Schofield, LMHC. dated November 8, Pacific Northwest National Laboratory, Richland, Washington..

Bos, S. J., 1999c, Untitled memorandum to J. S. Schofield, LMHC, dated November 16, Pacific Northwest National Laboratory, Richland, Washington.

Bos, S. J., 1999d, Untitled memorandum to J. S. Schofield, LMHC, dated November 9, Pacific Northwest National Laboratory, Richland, Washington.

Bos, S. J., 1999e, Untitled memorandum to J. S. Schofield, LMHC, dated November 11, Pacific Northwest National Laboratory, Richland, Washington.

CHG 2000a, Tank Waste Remediation System Final Safety Analysis Report, HNF-SD-WM-SAR-067, Rev. 1-K, CH2M HILL Hanford Group, Inc., Richland, Washington.

CHG 2000b, Technical Safety Requirements, TSR-006, Rev. 1-K, CH2M HILL Hanford Group, Inc., Richland, Washington.

Dodd, R. A., 2000, ER-311 Flammable Gas Response and Findings, HNF-5985, Rev. 0, CH2M HILL Hanford Group, Inc., Richland, Washington.

Dukelow, G. T., J. W. Hunt, H. Babad, and J. E. Meacham, 1995, Tank Safety Screening Data Quality Objective, WHC-SD-WM-SP-004, Rev. 2, Westinghouse Hanford Company, Richland, Washington.

LMHC 2000, Tank Farm Operations Administrative Controls, HNF-IP-1266, Rev. 1h, Lockheed Martin Hanford Corporation, Richland, Washington.

Nguyen, D. M., 1999a, Sampling and Analysis Plan for Catch Tank 241-ER-311 Vapor, RPP-5375, Rev. 2, CH2M HIIL Hanford Group, Inc., Richland, Washington.

Nguyen, D. M., 1999b, Sampling and Analysis Plan for Catch Tank 241-ER-311 Waste, RPP-5382, Rev. 1, CH2M HILL Hanford Group, Inc., Richland, Washington.

Nguyen, D. M., 2000, Test Plan for Measuring Ventilation Rates and Combustible Gas Levels in RPP Catch Tanks, HNF-4082, Rev. 4-A, CH2M HILL Hanford Group, Inc., Richland, Washington. 


\section{RPP-7022 Rev. 0}

Palit, A. N., 1996, Catch Tanks Inhibitor Addition - 200 East and 200 West Areas, WHC-SD-WM-ER-573, Rev. 0, ICF Kaiser Hanford Company, Richland, Washington.

Sasaki, L. M., 1999, Tank 241-ER-311 Interconnected Piping and Equipment Vapor Sampling and Analysis Plan, RPP-5377, Rev. 0, CH2M HILL Hanford Group, Inc., Richland, Washington.

Stauffer, M., 2000, Tank Vapor Sampling and Analysis Data Package for Catch Tank 241-ER-311, Sampled November 1-10, 1999, HNF-5757, Rev. 0, Fluor Hanford Inc., Richland, Washington.

Steen, F. H., 2000, Tank 241-ER-311 Grab Samples, Analytical Results for the Final Report, HNF-1690, Rev. 0, Waste Management of Hanford, Inc., Richland, Washington. 
RPP-7022 Rev. 0

APPENDIX A

SUMMARY OF VAPOR SAMPLING DATA FOR CATCH TANK 241-ER-311

A-1 
RPP-7022 Rev. 0

A-2 
RPP-7022 Rev. 0

Table A-1. Combustible Gas Meter Results from East Riser. (4 Sheets)

\begin{tabular}{|c|c|c|c|c|c|c|c|}
\hline Date/Tines. & \% L L & $\% 1 \mathrm{Ft}$ & $\%$ at Sft. & $\%$ at $10 \mathrm{ft}$ & $\%$ & $\begin{array}{l}\% \text { Lfl. } \\
\text { at } 20 \text {. }\end{array}$ & $\%$ \\
\hline $11 / 1 / 9911: 34$ & & $>100$ & & & & & \\
\hline $11 / 1 / 9911: 55$ & & $>100$ & & & & & \\
\hline \multicolumn{8}{|l|}{$11 / 1 / 9911: 56$} \\
\hline $11 / 1 / 9912: 26$ & & $>100$ & & & & & \\
\hline 11/1/99 12:44 & & & & & & $>100$ & $>100$ \\
\hline $11 / 1 / 9912: 48$ & & & & & & $>100$ & $>100$ \\
\hline \multicolumn{8}{|l|}{ 11/1/99 13:00 } \\
\hline \multicolumn{8}{|l|}{$11 / 04 / 199921: 35$} \\
\hline \multicolumn{8}{|l|}{$11 / 04 / 199921: 54$} \\
\hline \multicolumn{8}{|l|}{$11 / 04 / 1999 \quad 22: 40$} \\
\hline \multicolumn{8}{|l|}{$11 / 04 / 199922: 44$} \\
\hline $11 / 4 / 9922: 57$ & 0 & & 0 & & & & \\
\hline $11 / 4 / 9922: 59$ & 50 & & & & & & \\
\hline 11/4/9923:00 & 40 & & & & & & \\
\hline $11 / 4 / 9923: 02$ & 22 & & & & & & \\
\hline $11 / 4 / 9923: 04$ & 13 & & & & & & \\
\hline $11 / 4 / 9923: 07$ & 3 & & & & & & \\
\hline $11 / 4 / 9923: 15$ & 3 & & & & & & \\
\hline $11 / 4 / 9923: 37$ & 6 & & & & & & \\
\hline $11 / 4 / 9923: 48$ & 12 & & & & & & \\
\hline $11 / 5 / 9900: 03$ & 5 & & & & & & \\
\hline 11/5/9900:18 & 0 & & & & & & \\
\hline $11 / 5 / 9900: 33$ & 0 & & & & & & \\
\hline $11 / 5 / 9900: 48$ & 0 & & & & & & \\
\hline 11/5/9901:03 & 0 & & & & & & \\
\hline 11/5/9901:18 & 0 & & & & & & \\
\hline $11 / 5 / 9901: 33$ & 0 & & & & & & \\
\hline $11 / 5 / 9901: 48$ & 0 & & & & & & \\
\hline $11 / 5 / 9902: 03$ & 0 & & & & & & \\
\hline $11 / 5 / 9902: 18$ & 0 & & & & & & \\
\hline $11 / 5 / 9902: 33$ & 0 & & & & & & \\
\hline$1 1 / 5 / 9 9 \longdiv { 0 2 : 4 8 }$ & 0 & & & & & & \\
\hline $11 / 5 / 9903: 03$ & 0 & & & & & & \\
\hline $11 / 5 / 9903: 18$ & 0 & & & & & & \\
\hline $11 / 5 / 9903: 33$ & 0 & & & & & & \\
\hline $11 / 5 / 9903: 48$ & 0 & & & & & & \\
\hline $11 / 5 / 9904: 03$ & 0 & & & & & & \\
\hline $11 / 5 / 9904: 18$ & 0 & & & & & & \\
\hline $11 / 5 / 9904: 33$ & 0 & & & & & & \\
\hline $11 / 5 / 9904: 48$ & 0 & & & & & & \\
\hline $11 / 5 / 9905: 03$ & 0 & & & & & & \\
\hline $11 / 5 / 9905: 18$ & 0 & & & & & & \\
\hline $11 / 5 / 9905: 33$ & 0 & & & & & & \\
\hline
\end{tabular}


RPP-7022 Rev. 0

Table A-1. Combustible Gas Meter Results from East Riser. (4 Sheets)

\begin{tabular}{|c|c|c|c|c|c|c|c|}
\hline DatedTine & $\%$ a.1. & at $3 \mathrm{n}$ & \%1FI. & $\%$ & $\%$ & \% $20 \mathrm{ft}$. & $\%$ at $23 \pi$ \\
\hline 11/5/9905:48 & 0 & & & & & & \\
\hline $11 / 5 / 9906: 03$ & 0 & & & & & & \\
\hline $11 / 5 / 9906: 18$ & 0 & & & & & & \\
\hline $11 / 5 / 9906: 33$ & 0 & & & & & & \\
\hline $11 / 5 / 9906: 48$ & 0 & & & & & & \\
\hline $11 / 5 / 9907: 03$ & 0 & & & & & & \\
\hline 11/5/9907:18 & 0 & & & & & & \\
\hline $11 / 5 / 9907: 33$ & 0 & & & & & & \\
\hline $11 / 5 / 9907: 48$ & 0 & & & & & & \\
\hline $11 / 5 / 9908: 03$ & 0 & & & & & & \\
\hline $11 / 5 / 9908: 18$ & 0 & & & & & & \\
\hline $11 / 5 / 9908: 33$ & 0 & & & & & & \\
\hline $11 / 5 / 9908: 48$ & 0 & & & & & & \\
\hline $11 / 5 / 9909: 03$ & 0 & & & & & & \\
\hline $11 / 5 / 99$ 09:18 & 0 & & & & & & \\
\hline $11 / 5 / 9909: 33$ & 0 & & & & & & \\
\hline I 1/5/99 09:48 & 0 & & & & & & \\
\hline $11 / 5 / 9910: 03$ & 0 & & & & & & \\
\hline 11/5/99 10:18 & 0 & & & & & & \\
\hline $11 / 5 / 99 \quad 10: 33$ & 0 & & & & & & \\
\hline $11 / 5 / 9910: 48$ & 0 & & & & & & \\
\hline $11 / 5 / 9911: 03$ & 0 & & & & & & \\
\hline 11/5/99 $11: 18$ & 0 & & & & & & \\
\hline $11 / 5 / 9911: 33$ & 0 & & & & & & \\
\hline $11 / 5 / 9911: 41$ & 0 & & & & & & \\
\hline $11 / 5 / 9911: 48$ & 0 & & 2 & & & & \\
\hline $11 / 5 / 9911: 53$ & & & & & 131 & & \\
\hline $11 / 5 / 9911: 57$ & & & & & & 287 & \\
\hline $11 / 5 / 99 \quad 12: 03$ & 0 & & & & & & \\
\hline $11 / 5 / 9912: 05$ & & & & & & & 343 \\
\hline $11 / 5 / 99 \quad 12: 18$ & 0 & & & & & & \\
\hline $11 / 5 / 99 \quad 12: 33$ & 0 & & & & & & \\
\hline $11 / 5 / 9912: 48$ & 0 & & & & & & \\
\hline $11 / 5 / 9913: 03$ & 0 & & & & & & \\
\hline 11/5/99 13:18 & 0 & & & & & & \\
\hline $11 / 5 / 9914: 20$ & 0 & & & & & & \\
\hline $11 / 5 / 9914: 35$ & 0 & & 0 & & 131 & 287 & 343 \\
\hline $11 / 5 / 9914: 50$ & 2 & & & & & & \\
\hline $11 / 5 / 9915: 05$ & 1 & & & & & & \\
\hline $11 / 5 / 9915: 48$ & 3 & & & & & & \\
\hline $11 / 5 / 9916: 03$ & 3 & & & & & & \\
\hline $11 / 5 / 9917: 00$ & 2 & & & & & & \\
\hline $11 / 5 / 9917: 15$ & 3 & & & & & & \\
\hline $11 / 5 / 9917: 30$ & 3 & & & & & & \\
\hline
\end{tabular}


Table A-1. Combustible Gas Meter Results from East Riser. (4 Sheets)

\begin{tabular}{|c|c|c|c|c|c|c|c|}
\hline Dater Time & $\%$ 1.11 & \%1. 31 . & at sfl. & \%t 10r. & \%or. $1 \mathrm{st}$ & 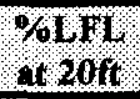 & $\%$ \\
\hline $11 / 5 / 9917: 45$ & 4 & & & & & & \\
\hline $11 / 5 / 99 \quad 18: 30$ & 4 & & & & & & \\
\hline $11 / 5 / 9918: 45$ & 4 & & & & & & \\
\hline $11 / 5 / 9919: 00$ & 4 & & & & & & \\
\hline $11 / 5 / 9920: 15$ & 5 & & & & & & \\
\hline $11 / 5 / 9920: 30$ & 6 & & & & & & \\
\hline $11 / 5 / 9920: 45$ & 5 & & & & & & \\
\hline $11 / 5 / 9921: 00$ & 5 & & & & & & \\
\hline $11 / 5 / 9921: 15$ & 0 & & & & & & \\
\hline $11 / 5 / 9923: 41$ & 0 & & & & & & \\
\hline $11 / 5 / 9923: 48$ & & & 2 & & & & \\
\hline $11 / 5 / 9923: 53$ & & & & & 131 & & \\
\hline $11 / 5 / 9923: 57$ & & & & & & 287 & \\
\hline \multicolumn{8}{|l|}{$11 / 6 / 990: 01$} \\
\hline $11 / 6 / 990: 05$ & & & & & & & 343 \\
\hline $11 / 6 / 991: 30$ & 0 & & & & & & \\
\hline $11 / 6 / 991: 30$ & & & 2 & & & & \\
\hline $11 / 6 / 992: 30$ & & & 0 & & & & \\
\hline $11 / 6 / 993: 00$ & & & & & & & 61 \\
\hline $11 / 6 / 994: 15$ & & & & & & & 48 \\
\hline $11 / 6 / 994: 30$ & & & & & & & 44 \\
\hline $11 / 6 / 994: 45$ & & & & & & & 15 \\
\hline $11 / 6 / 994: 45$ & & & & & & & 8 \\
\hline $11 / 6 / 995: 00$ & & & & & & & 1 \\
\hline $11 / 6 / 995: 15$ & & & & & & & 1 \\
\hline $11 / 6 / 995: 30$ & & & & & & & 1 \\
\hline $11 / 6 / 996: 00$ & & & & & & & 1 \\
\hline $11 / 6 / 997: 45$ & & & & & & & 0 \\
\hline \multicolumn{8}{|l|}{$11 / 6 / 997: 50$} \\
\hline $11 / 6 / 998: 45$ & & & & & & & 0 \\
\hline \multicolumn{8}{|l|}{ 11/6/99 8:50 } \\
\hline $11 / 6 / 999: 45$ & & & & & & & 0 \\
\hline \multicolumn{8}{|l|}{$11 / 6 / 999: 50$} \\
\hline $11 / 6 / 99 \quad 10: 50$ & & & & & & & 0 \\
\hline \multicolumn{8}{|l|}{$11 / 6 / 99 \quad 10: 55$} \\
\hline $11 / 7 / 991: 55$ & & & 0 & & & & \\
\hline $11 / 7 / 991: 55$ & & & & & & & 0 \\
\hline $11 / 7 / 993: 30$ & & & 0 & & & & \\
\hline $11 / 7 / 993: 30$ & & & & & & & 0 \\
\hline $11 / 7 / 994: 00$ & & & 0 & & & & \\
\hline $11 / 7 / 994: 00$ & & & & & & & 0 \\
\hline 11/7/996:00 & & & 0 & & & & \\
\hline $11 / 7 / 996: 00$ & & & & & & & 0 \\
\hline $11 / 7 / 998: 00$ & & & 0 & & & & \\
\hline
\end{tabular}


RPP-7022 Rev. 0

Table A-1. Combustible Gas Meter Results from East Riser. (4 Sheets)

\begin{tabular}{|c|c|c|c|c|c|c|c|}
\hline Date/Time & $\%$ at. $1 \mathrm{ft}$. & at 3 nt & $\begin{array}{l}\% 1 \% \text {. } \\
\text { at } 5 \mathrm{~T} \text {. }\end{array}$ & at lort. & 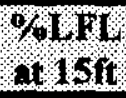 & \% 201 . & $\%$ at $23 \pi$ \\
\hline $11 / 7 / 998: 00$ & & & & & & & 0 \\
\hline $11 / 7 / 9910: 10$ & & & 0 & & & & \\
\hline $11 / 7 / 99 \quad 10: 10$ & & & & & & & 0 \\
\hline $11 / 7 / 9912: 00$ & & & 0 & & & & \\
\hline $11 / 7 / 9912: 00$ & & & & & & & 0 \\
\hline $11 / 7 / 99 \quad 14: 10$ & & & 0 & & & & \\
\hline 11/7/99 14:10 & & & & & & & 0 \\
\hline $11 / 7 / 9916: 00$ & & & 0 & & & & \\
\hline $11 / 7 / 99 \quad 16: 00$ & & & & & & & 0 \\
\hline $11 / 7 / 9918: 10$ & & & & & & & 0 \\
\hline $11 / 7 / 9920: 00$ & & & & & & & 0 \\
\hline $11 / 7 / 9922: 00$ & & & & & & & 0 \\
\hline $11 / 08 / 1999 \quad 10: 00$ & & & 0 & & & & 0 \\
\hline $11 / 08 / 1999 \quad 12: 00$ & & & 0 & & & & 0 \\
\hline $11 / 08 / 1999 \quad 14: 00$ & & & 0 & & & & 0 \\
\hline $11 / 08 / 1999 \quad 16: 00$ & & & 0 & & & & 0 \\
\hline $11 / 08 / 1999 \quad 18: 00$ & & & I & & & I & \\
\hline $11 / 08 / 199920: 00$ & & & 0 & & & & 0 \\
\hline $11 / 09 / 1999 \quad 00: 00$ & 0 & 0 & & & & 0 & \\
\hline $11 / 09 / 199900: 02$ & & & & & & & 0 \\
\hline $11 / 09 / 1999 \quad 02: 00$ & 0 & & & & & & \\
\hline 11/09/1999 02:02 & & & & & & & 0 \\
\hline $11 / 09 / 199904: 03$ & 0 & & & & & & \\
\hline $11 / 09 / 199904: 05$ & & & & & & & 5 \\
\hline $11 / 09 / 199906: 03$ & 0 & & & & & & \\
\hline $11 / 09 / 1999 \quad 06: 05$ & & & & & & & 3 \\
\hline $11 / 10 / 199901: 45$ & 0 & & & & & & \\
\hline $11 / 10 / 199902: 50$ & 0 & & & & & & \\
\hline $11 / 12 / 1999 \quad 16: 05$ & & & 0 & & & 0.0 & \\
\hline $11 / 21 / 199911: 30$ & 3 & 4 & & & & 6 & \\
\hline $\begin{array}{l}11 / 21 / 1999 \\
12: 05^{*} \\
\end{array}$ & & & & & & 0 & \\
\hline
\end{tabular}

* Note: Measurement on 11/21/1999 at 12:05 PM was obtained after the plastic liner was removed from the East riser. 
RPP-7022 Rev. 0

Table A-2. Hoke ${ }^{\mathrm{TM}}$ Sample Results from East Riser

\begin{tabular}{|c|c|c|c|c|c|c|}
\hline GAS SPECIES & $\begin{array}{l}\text { Date Sampled: } \\
\text { Location } 2317 \text { it } \\
\text { Mole \% }\end{array}$ & 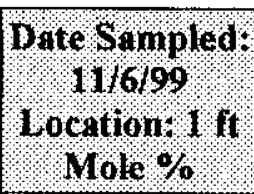 & 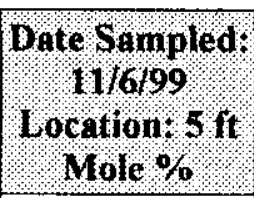 & $\begin{array}{l}\text { Date Sanpled } \\
\text { Location: } 15 \text { fit } \\
\text { Mole \% }\end{array}$ & 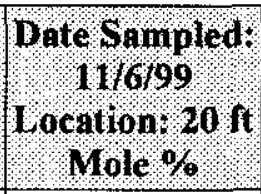 & 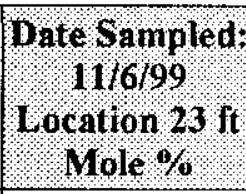 \\
\hline Argon & 0.72 & 0.93 & 0.93 & 0.89 & 0.85 & 0.84 \\
\hline Carbon Dioxide & 19.4 & 0.056 & 0.08 & 6.2 & 12.2 & 13.8 \\
\hline Carbon Monoxide & $<0.01$ & $<0.1$ & $<0.1$ & $<0.1$ & $<0.1$ & $<0.1$ \\
\hline Helium & $<0.001$ & $<0.001$ & $<0.001$ & $<0.001$ & $<0.001$ & $<0.001$ \\
\hline Hydrogen & 16.3 & 0.016 & 0.046 & 1.86 & 3.43 & 3.84 \\
\hline Mcthane & $<0.021$ & 0.001 & 0.001 & 0.007 & 0.012 & $<0.014$ \\
\hline Nitrogen & 54.2 & 77.9 & 77.9 & 72.7 & 67.9 & 66.8 \\
\hline Oxygen & 9.41 & 21.1 & 21.1 & 18.3 & 15.6 & 14.8 \\
\hline Nitrous Oxide & $<0.01$ & $<0.01$ & $<0.01$ & $<0.01$ & $<0.01$ & $<0.01$ \\
\hline $\begin{array}{l}\text { Other Nitrogen } \\
\text { Oxides }\end{array}$ & $<0.005$ & $<0.005$ & $<0.005$ & $<0.005$ & $<0.005$ & $<0.005$ \\
\hline Other Hydrocarbons & $<0.01$ & $<0.001$ & $<0.001$ & 0.006 & 0.01 & $<0.01$ \\
\hline Ammonia (cstimate) & $<0.001$ & $<0.001$ & $<0.001$ & $<0.001$ & $<0.001$ & $<0.001$ \\
\hline
\end{tabular}


Table A-3. SUMMA ${ }^{\mathrm{TM}}$ Sample Results from East Riser. (2 Sheets)

\begin{tabular}{|c|c|c|c|c|}
\hline 4044 Hos & 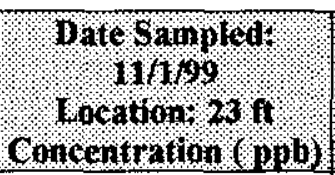 & 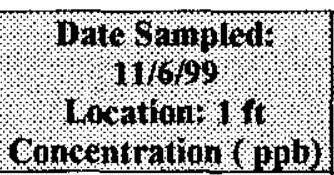 & 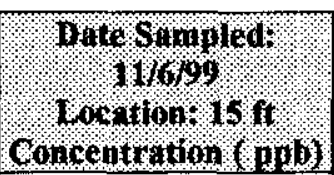 & 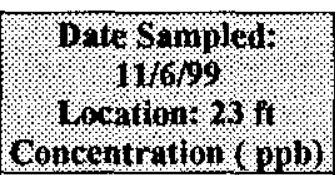 \\
\hline Freon 12 & $<5.0$ & $<5.0$ & $<5.0$ & $<5.0$ \\
\hline Methyl Chloride & 41 & $<5.0$ & 22 & 90 \\
\hline N-Butane & 850 & $<5.0$ & 690 & 1900 \\
\hline Ethyl Chloride & 7.4 & $<5.0$ & $<5.0$ & 8.5 \\
\hline Freon 11 & $<5.0$ & $<5.0$ & $<5.0$ & $<5.0$ \\
\hline N-Pentane & 770 & $<5.0$ & 310 & 1100 \\
\hline Dichloromethane & $<5.0$ & $<5.0$ & 6.5 & $<5.0$ \\
\hline 2-Methyl-Pentane & 190 & $<5.0$ & 85 & 290 \\
\hline 1-Hexanc & 30 & $<5.0$ & 18 & 65 \\
\hline N-Hexane & 200 & $<5.0$ & 98 & 340 \\
\hline Chloroform & $<5.0$ & $<5.0$ & $<5.0$ & $<5.0$ \\
\hline Benzene & 6.9 & $<5.0$ & 8.1 & 25 \\
\hline Carbon Tetrachloride & $<5.0$ & $<5.0$ & $<5.0$ & $<5.0$ \\
\hline 3-Mcthyl-Hexane & 20 & $<5.0$ & 27 & 63 \\
\hline $\mathrm{N}-\mathrm{Heptanc}$ & 77 & $<5.0$ & 70 & 240 \\
\hline Toluene & 6.6 & $<5.0$ & 140 & 380 \\
\hline N-Octane & $<5.0$ & $<5.0$ & 46 & 150 \\
\hline Telrachlorocthylene & $<5.0$ & $<5.0$ & $<5.0$ & $<5.0$ \\
\hline Chlorobenzene & $<5.0$ & $<5.0$ & $<5.0$ & $<5.0$ \\
\hline Ethylbenzenc & $<5.0$ & $<5.0$ & 18 & 58 \\
\hline M, P-Xylene & $<5.0$ & $<5.0$ & 32 & 72 \\
\hline Styrenc & $<5.0$ & $<5.0$ & $<5.0$ & $<5.0$ \\
\hline N-Nonane & $<5.0$ & $<5.0$ & 92 & 320 \\
\hline $\begin{array}{l}1,1,2,2- \\
\text { Tetrachloroethane }\end{array}$ & $<5.0$ & $<5.0$ & $<5.0$ & $<5.0$ \\
\hline 0 -Xylenc & $<5.0$ & $<5.0$ & 6.2 & 13 \\
\hline N-Decane & $<5.0$ & $<5.0$ & $<5.0$ & 100 \\
\hline $\begin{array}{l}1,2,4- \\
\text { Trimethylbenzenc }\end{array}$ & $<5.0$ & $<5.0$ & $<5.0$ & $<5.0$ \\
\hline Ethanol & 10 & $<5.0$ & 27 & $<5.0$ \\
\hline Acetonitrile & $<5.0$ & $<5.0$ & $<5.0$ & $<5.0$ \\
\hline Acetone & $<5.0$ & $<5.0$ & 96 & 120 \\
\hline Furan & $<5.0$ & $<5.0$ & $<5.0$ & $<5.0$ \\
\hline 2-Propanol & $<5.0$ & $<5.0$ & $<5.0$ & $<5.0$ \\
\hline 1-Propanol & $<5.0$ & $<5.0$ & $<5.0$ & $<5.0$ \\
\hline Propancnitrile & $<5.0$ & $<5.0$ & $<5.0$ & $<5.0$ \\
\hline Butanal & $<5.0$ & $<5.0$ & 24 & 38 \\
\hline 2-Butanone & $<5.0$ & $<5.0$ & 22 & 20 \\
\hline Tetrahydrofuran & $<5.0$ & $<5.0$ & $<5.0$ & $<5.0$ \\
\hline 1-Butanol & $<5.0$ & $<5.0$ & $<5.0$ & $<5.0$ \\
\hline Butancnitrile & $<5.0$ & $<5.0$ & $<5.0$ & $<5.0$ \\
\hline 2-Pcntanone & $<5.0$ & $<5.0$ & 39 & 68 \\
\hline 1, 4-Dioxane & $<5.0$ & $<5.0$ & $<5.0$ & $<5.0$ \\
\hline
\end{tabular}


RPP-7022 Rev. 0

Table A-3. SUMMA ${ }^{\mathrm{TM}}$ Sample Results from East Riser. (2 Sheets)

\begin{tabular}{|c|c|c|c|c|}
\hline ANGYYULS & 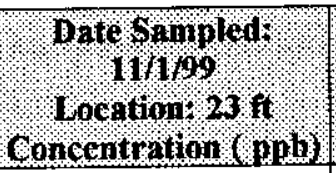 & 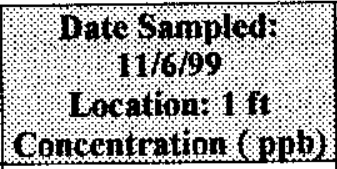 & 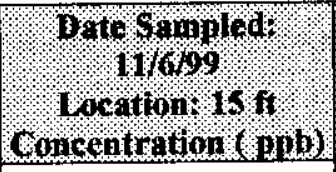 & 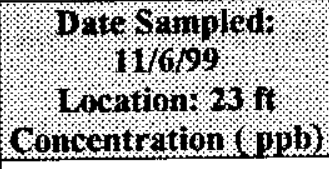 \\
\hline $\begin{array}{l}\text { 4-Methyl-2- } \\
\text { Pentanone }\end{array}$ & $<5.0$ & $<5.0$ & $<5.0$ & $<5.0$ \\
\hline 2-Hexanone & $<5.0$ & $<5.0$ & $<5.0$ & $<5.0$ \\
\hline 3-Heptanone & $<5.0$ & $<5.0$ & $<5.0$ & $<5.0$ \\
\hline 2-Heptanone & $<5.0$ & $<5.0$ & $<5.0$ & $<5.0$ \\
\hline Cyclohexanone & $<5.0$ & $<5.0$ & $<5.0$ & $<5.0$ \\
\hline 2-Octanone & $<\overline{5.0}$ & $<5.0$ & $<5.0$ & $<5.0$ \\
\hline Hydrogen & $120000 \mathrm{ppm}$ & $86 \mathrm{ppm}$ & $9800 \mathrm{ppm}$ & $29000 \mathrm{ppm}$ \\
\hline Methane & $110 \mathrm{ppm}$ & $<50$ ppm & $<50 \mathrm{ppm}$ & $100 \mathrm{ppm}$ \\
\hline Carbon Dioxide & $130000 \mathrm{ppm}$ & $420 \mathrm{ppm}$ & $17000 \mathrm{ppm}$ & $52000 \mathrm{ppm}$ \\
\hline Nitrous Oxide & $<50 \mathrm{ppm}$ & $<50 \mathrm{ppm}$ & $<50 \mathrm{ppm}$ & $<50 \mathrm{ppm}$ \\
\hline Carbon Monoxide & $<50 \mathrm{ppm}$ & $<50 \mathrm{ppm}$ & $<50 \mathrm{ppm}$ & $<50 \mathrm{ppm}$ \\
\hline
\end{tabular}


RPP-7022 Rev. 0

Table A-4. Hoke ${ }^{\mathrm{TM}}$ Results from West Riser

\begin{tabular}{|c|c|c|c|c|c|}
\hline ANATYTE: & 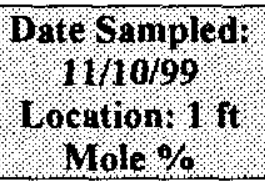 & $\begin{array}{l}\text { Date Sampled? } \\
\text { Location: } 5 \text { ift } \\
\text { Mole } \%\end{array}$ & $\begin{array}{l}\text { Date Sampled } \\
\text { Location: } 1 \mathrm{~s} \text { ft } \\
\text { Mole \% }\end{array}$ & $\begin{array}{l}\text { Date Sampled } \\
11110999 \\
\text { Location } 20 \mathrm{ft}\end{array}$ & $\begin{array}{l}\text { Dite Sampled: } \\
11 / 10 / 99 \\
.0 \text { cation } 23 \mathrm{ft}\end{array}$ \\
\hline Argon & 0.94 & 0.93 & 0.93 & 0.94 & 0.94 \\
\hline Carbon Dioxide & 0.042 & 0.039 & 0.037 & 0.042 & 0.041 \\
\hline $\begin{array}{l}\text { Carbon } \\
\text { Monoxide }\end{array}$ & $<0.01$ & $<0.01$ & $<0.01$ & $<0.01$ & $<0.01$ \\
\hline Helium & $<0.001$ & $<0.001$ & $<0.001$ & $<0.001$ & $<0.001$ \\
\hline Hydrogen & $<0.001$ & $<0.001$ & $<0.001$ & $<0.001$ & $<0.001$ \\
\hline Methane & $<0.001$ & $<0.001$ & $<0.001$ & $<0.001$ & $<0.001$ \\
\hline Nitrogen & 77.9 & 77.9 & 77.9 & 77.9 & 77.9 \\
\hline Oxygen & 21.1 & 21.1 & 21.1 & 21.1 & 21.1 \\
\hline Nitrous Oxide & $<0.005$ & $<0.005$ & $<0.005$ & $<0.005$ & $<0.005$ \\
\hline $\begin{array}{l}\text { Other Nitrogen } \\
\text { Oxides }\end{array}$ & $<0.005$ & $<0.005$ & $<0.005$ & $<0.005$ & $<0.005$ \\
\hline $\begin{array}{l}\text { Other } \\
\text { Hydrocarbons }\end{array}$ & $<0.001$ & $<0.001$ & $<0.001$ & $<0.001$ & $<0.001$ \\
\hline $\begin{array}{l}\text { Ammonia } \\
\text { (estimate) }\end{array}$ & $<0.001$ & $<0.001$ & $<0.001$ & $<0.001$ & $<0.001$ \\
\hline
\end{tabular}


Table A-5. SUMMA ${ }^{T M}$ Results from West Riser. (2 Sheets)

\begin{tabular}{|c|c|c|c|}
\hline ANALNTES & 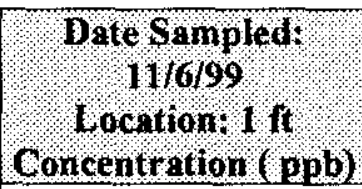 & 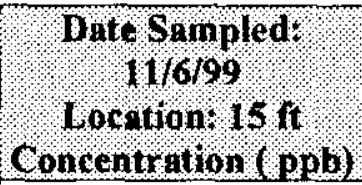 & $\begin{array}{l}\text { Date Sampled, } \\
\text { Location } 23 \mathrm{ft} \text {. } \\
\text { Concentration ( epb) }\end{array}$ \\
\hline Freon 12 & $<5.0$ & $<5.0$ & $<5.0$ \\
\hline Methyl Chloride & $<5.0$ & $<5.0$ & $<5.0$ \\
\hline N-Butane & $<5.0$ & $<5.0$ & $<5.0$ \\
\hline Ethyl Chloride & $<5.0$ & $<5.0$ & $<5.0$ \\
\hline Freon 11 & $<5.0$ & $<5.0$ & $<5.0$ \\
\hline N-Pentane & $<5.0$ & $<5.0$ & $<5.0$ \\
\hline Dichloromethane & $<5.0$ & $<5.0$ & $<5.0$ \\
\hline 2-Methyl-Pentane & $<5.0$ & $<5.0$ & $<5.0$ \\
\hline 1-Hexane & $<5.0$ & $<5.0$ & $<5.0$ \\
\hline $\mathrm{N}-\mathrm{Hexanc}$ & $<5.0$ & $<5.0$ & $<5.0$ \\
\hline Chloroform & $<5.0$ & $<5.0$ & $<5.0$ \\
\hline Benzenc & $<5.0$ & $<5.0$ & $<5.0$ \\
\hline Carbon Tetrachloride & $<5.0$ & $<5.0$ & $<5.0$ \\
\hline 3-Methyl-Hexane & $<5.0$ & $<5.0$ & $<5.0$ \\
\hline N-Heptane & $<5.0$ & $<5.0$ & $<5.0$ \\
\hline Toluene & $<5.0$ & $<5.0$ & $<5.0$ \\
\hline N-Octane & $<5.0$ & $<5.0$ & $<\overline{5.0}$ \\
\hline Tetrachloroethylene & $<5.0$ & $<5.0$ & $<5.0$ \\
\hline Chlorobenzene & $<5.0$ & $<5.0$ & $<5.0$ \\
\hline Ethylbenzene & $<5.0$ & $<5.0$ & $<5.0$ \\
\hline M, P-Xylenc & $<5.0$ & $<5.0$ & $<5.0$ \\
\hline Styrene & $<5.0$ & $<5.0$ & $<5.0$ \\
\hline $\mathrm{N}$-Nonanc & $<5.0$ & $<5.0$ & $<5.0$ \\
\hline $\begin{array}{l}1,1,2,2- \\
\text { Tetrachloroethane }\end{array}$ & $<5.0$ & $<5.0$ & $<5.0$ \\
\hline $0-X y l e n c$ & $<5.0$ & $<5.0$ & $<5.0$ \\
\hline N-Decane & $<5.0$ & $<5.0$ & $<5.0$ \\
\hline 1,2,4-Trimethylbenzenc & $<5.0$ & $<5.0$ & $<5.0$ \\
\hline Ethanol & $<5.0$ & $<5.0$ & $<5.0$ \\
\hline Acetonitrile & $<5.0$ & $<5.0$ & $<5.0$ \\
\hline Acetone & $<5.0$ & $<5.0$ & $<5.0$ \\
\hline Furan & $<5.0$ & $<5.0$ & $<5.0$ \\
\hline 2-Propanol & $<5.0$ & $<5.0$ & $<5.0$ \\
\hline 1-Propanol & $<5.0$ & $<5.0$ & $<5.0$ \\
\hline Propanenitrile & $<5.0$ & $<5.0$ & $<5.0$ \\
\hline Butanal & $<5.0$ & $<5.0$ & $<5.0$ \\
\hline 2-Butanone & $<5.0$ & $<5.0$ & $<5.0$ \\
\hline Tetrahydrofuran & $<5.0$ & $<5.0$ & $<5.0$ \\
\hline
\end{tabular}


Table A-5. SUMMA ${ }^{\mathrm{TM}}$ Results from West Riser. (2 Sheets)

\begin{tabular}{|c|c|c|c|}
\hline AMALYTES & 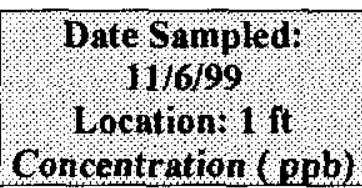 & $\begin{array}{l}\text { Date Sampled: } \\
1 / 16 / 99 \\
\text { Cocation. } 15 \text { it } \\
\text { Concentration (ppb) }\end{array}$ & $\begin{array}{l}\text { Date Sampled } \\
116.99 \\
\text { Concention. } 23 \text { ft } \\
\text { Contration ( ppb) }\end{array}$ \\
\hline 1-Butanol & $<5.0$ & $<5.0$ & $<5.0$ \\
\hline Butanenitrile & $<5.0$ & $<5.0$ & $<5.0$ \\
\hline 2-Pentanone & $<5.0$ & $<5.0$ & $<5.0$ \\
\hline 1, 4-Dioxane & $<5.0$ & $<5.0$ & $<5.0$ \\
\hline 4-Methyl-2-Pentanone & $<5.0$ & $<5.0$ & $<5.0$ \\
\hline 2-Hexanone & $<5.0$ & $<5.0$ & $<5.0$ \\
\hline 3-Heptanone & $<5.0$ & $<5.0$ & $<5.0$ \\
\hline 2-Hcptanone & $<5.0$ & $<5.0$ & $<5.0$ \\
\hline Cyclohexanone & $<\overline{5.0}$ & $<5.0$ & $<5.0$ \\
\hline 2-Octanone & $<5.0$ & $<5.0$ & $<5.0$ \\
\hline Hydrogen & $<50 \mathrm{ppm}$ & $<50 \mathrm{ppm}$ & $<50 \mathrm{ppm}$ \\
\hline Methane & $<50 \mathrm{ppm}$ & $<50 \mathrm{ppm}$ & $<50 \mathrm{ppm}$ \\
\hline Carbon Dioxide & $320 \mathrm{ppm}$ & $310 \mathrm{ppm}$ & $390 \mathrm{ppm}$ \\
\hline Nitrous Oxide & $<50 \mathrm{ppm}$ & $<50 \mathrm{ppm}$ & $<50 \mathrm{ppm}$ \\
\hline Carbon Monoxide & $<50 \mathrm{ppm}$ & $<50 \mathrm{ppm}$ & $<50 \mathrm{ppm}$ \\
\hline
\end{tabular}


RPP-7022 Rev. 0

Table A-6. Hoke ${ }^{T M}$ Results from Interconnected Piping and Equipment

\begin{tabular}{|c|c|c|c|c|c|}
\hline GAS SPECIES & $\begin{array}{l}\text { Date Sampled: } \\
\text { 11/6h1099; } \\
\text { Location; } \\
\text { TR-1-EW ( }) \\
\text { Mole\% }\end{array}$ & 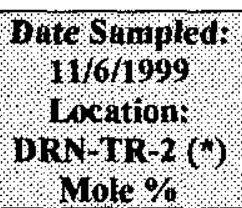 & 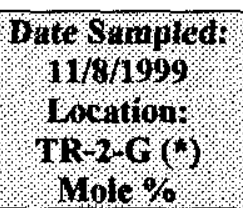 & 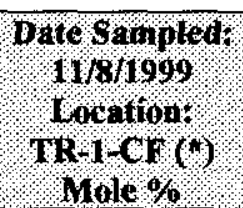 & $\begin{array}{l}\text { Date Sampled: } \\
11 / 9199 \\
\text { location: } \\
241-\mathrm{ER} \text { isi } \\
\text { Mole } \%\end{array}$ \\
\hline Argon & 11.6 & 0.93 & 0.93 & 0.93 & 24.6 \\
\hline Carbon Dioxide & 0.201 & 0.444 & 0.054 & 0.053 & 0.067 \\
\hline Carbon Monoxide & $<0.01$ & $<0.01$ & $<0.01$ & $<0.01$ & $<0.01$ \\
\hline Helium & $<0.001$ & $<0.001$ & $<0.001$ & $<0.001$ & $<0.001$ \\
\hline Hydrogen & $<0.001$ & 0.012 & $<0.001$ & 0.005 & 0.001 \\
\hline Methane & $<0.001$ & $<0.001$ & $<0.001$ & $<0.001$ & $<0.001$ \\
\hline Nitrogen & 69.6 & 77.8 & 77.9 & 77.9 & 59.6 \\
\hline Oxygen & 18.6 & 20.9 & 21.1 & $21 . \overline{1}$ & 15.8 \\
\hline Nitrous Oxide & $<0.01$ & $<0.01$ & $<0.01$ & 0.015 & 0.004 \\
\hline $\begin{array}{l}\text { Other Nitrogen } \\
\text { Oxides }\end{array}$ & $<0.005$ & $<0.005$ & $<0.005$ & $<0.005$ & $<0.005$ \\
\hline Other Hydrocarbons & $<0.001$ & $<0.001$ & $<0.001$ & $<0.001$ & $<0.001$ \\
\hline Ammonia (estimate) & $<0.001$ & $<0.001$ & $<0.001$ & $<0.001$ & $<0.001$ \\
\hline
\end{tabular}

Notes:

$\left({ }^{*}\right)$ The depth of the sample is approximately mid -point between top and bottom of riser 